NBER WORKING PAPER SERIES

THE ACCUMULATION OF HUMAN AND MARKET CAPITAL IN THE UNITED STATES:

THE LONG VIEW, 1948-2013

Barbara M. Fraumeni

Michael S. Christian

Jon D. Samuels

Working Paper 27170

http://www.nber.org/papers/w27170

\author{
NATIONAL BUREAU OF ECONOMIC RESEARCH \\ 1050 Massachusetts Avenue \\ Cambridge, MA 02138 \\ May 2020
}

The views expressed in this chapter are those of the authors and do not necessarily represent the U.S. Bureau of Economic Analysis, the U.S. Department of Commerce, or the National Bureau of Economic Research. We thank Mary-Lynne Neil of the Bureau of Economic Analysis for copyediting a draft version of this chapter.

NBER working papers are circulated for discussion and comment purposes. They have not been peer-reviewed or been subject to the review by the NBER Board of Directors that accompanies official NBER publications.

(C) 2020 by Barbara M. Fraumeni, Michael S. Christian, and Jon D. Samuels. All rights reserved. Short sections of text, not to exceed two paragraphs, may be quoted without explicit permission provided that full credit, including $\odot$ notice, is given to the source. 
The Accumulation of Human and Market Capital in the United States: The Long View, 1948-2013 Barbara M. Fraumeni, Michael S. Christian, and Jon D. Samuels

NBER Working Paper No. 27170

May 2020

JEL No. E01,E24,I21,J21,J24

\begin{abstract}
Over the 1948-2013 period, many factors significantly impacted on human capital, which in turn affected economic growth in the United States. This chapter analyzes these factors within a complete national income accounting system which integrates Jorgenson-Fraumeni human capital into the accounts. By including human capital, a fresh perspective on economic growth across time and within specific subperiods is revealed, notably regarding the 1995-2000 and 2007-2009 periods. During the 1995-2000 period, the reduction in human capital investment significantly reduced apparent economic growth. In the 2007-2009 period, the increase in human capital investment tempered the negative impact of the Great Recession. Over the longer time period, first the post-World War baby boom and then the substantial increase in education led to higher economic growth than otherwise expected. As the pace of increase in education slowed and the workforce aged toward the end of the period, human capital induced growth was reduced.
\end{abstract}

Barbara M. Fraumeni

Central University of Finance and Economics

770 Middle Road

Dresden, ME 04342

and NBER

Barbara_Fraumeni@hotmail.com

Michael S. Christian

Education Analytics

131 West Wilson St

\#200

Madison, WI 53703

mchristian@edanalytics.org
Jon D. Samuels

Bureau of Economic Analysis

Suitland, MD 20746

Jon.Samuels@bea.gov 


\title{
The Accumulation of Human and Market Capital in the United States:
}

\author{
The Long View, 1948-2013
}

Over the 1948-2013 period, many factors significantly impacted on human capital. In 1948, the post-World War II baby boom was well underway. The G.I. Bill (Servicemen's Readjustment Act of 1944) provided stipends for tuition and expenses for veterans attending colleges and trade schools, facilitating matriculation. The average educational attainment by both men and women increased by over 55 percent between 1950 and 2010. By 2010 women were on average slightly more educated than men and those aged 25-34 were almost seven percentage points more likely than men to complete tertiary education. Most of the labor force changes came from increasing participation by women. Civilian labor force participation for prime age (35-44 year old) women, rose from about 35 percent in 1950 to 77 percent in 2000, before declining slightly to 75 percent in 2010. Only about 23 percent of married women were part of the civilian labor force in 1948, but by 1970, this number had climbed to 41 percent. By 1980, the "V" drop in civilian female labor force participation during child-bearing ages had disappeared. Male prime age civilian labor force participation by decade peaked in 1970 at about 97 percent, then declined over the subsequent decades to less than 92 percent in 2010. Just over halfway through the covered period, in the mid-eighties, the so-called “Great Moderation” began. In this "moderation,” business cycles were less volatile, which tends to increase employment stability and therefore the potential pay-off from further education. ${ }^{1}$ Towards the end of the covered period, the 2007-2009 Great Recession ended this moderation and reduced employment significantly.

This chapter is the fourth in a series of human capital accounting papers using JorgensonFraumeni methodology. The first in this series established the methodology and emphasis used in subsequent papers (Jorgenson and Fraumeni, 1989). The second, published 28 years later, updated the accounts to reflect many changes in the U.S. national accounts over that time period. The period covered in the second paper includes a gap as human capital estimates from 1985 through 1997 (Fraumeni et al., 2017). The third is the only one in the series which breaks out human capital by gender (Fraumeni and Christian, 2019). As gender-specific estimates are not available in Jorgenson and Fraumeni (1989) the coverage of the 2019 paper begins in 1975. This chapter includes a much longer time period - 65 years - than in the previous three papers, accordingly the term "long view" is part of the chapter title. ${ }^{2}$ The human capital estimates from

\footnotetext{
${ }^{1}$ Bernanke (2004).

${ }^{2}$ Two other papers by Jorgenson and Fraumeni are frequently cited: Jorgenson and Fraumeni, 1992a and 1992b. 1992a is cited because it imbeds an education and human capital sector within an aggregate GDP account. The 1992b paper is cited because for the first time it includes the equations underlying the methodology.
} 
1948 through 1975 are from Jorgenson and Fraumeni (1989); those from 1976 are constructed by Christian (2017) and modified to more closely conform to the Jorgenson-Fraumeni methodology.

An important continuing contribution of this paper series is to integrate human capital estimates with the system of national accounts (SNA). The Bureau of Economic Analysis (BEA) National Income and Product Accounts (NIPA) data for this paper was collected subsequent to the 14th comprehensive revision of the NIPAs. ${ }^{1}$ Comprehensive revisions typically occur every five years (BEA, 2013: 13-39), accordingly many have occurred since 1948. The NIPAs are the basis for almost all of the core accounts data in this chapter except for human capital data. There have been many definitional, classification, source data, methodological, and presentation changes as a result of the revisions and it is important to integrate the human capital estimates with the latest definitions used in the U.S. national accounts. It was not until 1951 that constant dollar estimates of Gross National Product (GNP) were released (Jaszi and Kendrick, 1951). ${ }^{2}$ Many methodological or statistical improvements have been made since then. Boskin (2000) counted 160 revisions to nominal dollar Gross Domestic Product (GDP) in six comprehensive revisions beginning in 1976 and ending in 1999; certainly, many revisions occurred in the comprehensive revisions before and after the revisions he analyzed. A number of the revisions were concerned with prices or quality change, such as hedonic price indexes for computers and implementation of chained Fisher ideal indexes. Other changes include the classification of software, research and development, and entertainment and literary artistic originals as investment, separation of government expenditures into consumption versus investment, measurement of implicit services provided by property and casualty insurance and by commercial banks, and a complete revamping of the table presentation of the accounts. ${ }^{3}$ In addition, the NIPAs changed over time to be in greater conformity with the SNA. ${ }^{4}$

This chapter is organized into six sections: I) Human capital methodology, II) Factors impacting on human and market capital, III) Overview of the accounts, IV) Analysis of the accounts in nominal dollars, V) Analysis of contributions and rates of growth, and VI) Conclusion.

\section{Human Capital Methodology}

The measures of human capital employed in this account are based on the methodology of Jorgenson and Fraumeni (1989). The Jorgenson-Fraumeni approach measures human capital as nominal lifetime earnings, in present discounted value, of all living people--adults and children-in an economy. Quantities are measured using chain indexes with the exception of quantities such as net investment, which can include negative components; prices are implicitly determined from the nominal values and the quantities. ${ }^{5}$ The Jorgenson-Fraumeni approach includes both a

\footnotetext{
${ }^{1}$ The NIPA data is dated July 28, 2017.

${ }^{2}$ Gross National Product originally was the featured measure of the state of the economy.

${ }^{3}$ See Boskin (2000) and various issues of the Survey of Current Business (U.S. Department of Commerce).

${ }^{4}$ For example, the term operating surplus was introduced during the 2003 comprehensive revision.

${ }^{5}$ Quantities such as net investment, which can include negative components, are created using additive aggregation. Fisher indexes are the basis for underlying measures; Törnqvist indexes are used to create aggregates which include
} 
market component, which is measured using nominal lifetime market labor compensation, as well as a nonmarket component, which is measured using lifetime value of time spent in nonmarket activities other than schooling and personal maintenance. Including nonmarket activities during the 1948 to 2013 period is particularly important as notably women changed time spent in various activities. Time spent in nonmarket work decreased as time spent in market work increased.

The Jorgenson-Fraumeni approach measures nominal lifetime earnings, using equation (1):

$$
\begin{array}{r}
i_{y, a, s, e}=y i_{y, a, s, e}+\left[(1+\rho)^{-1}(1+g) s r_{y, a, s}\right] \operatorname{senr}_{y, a+1, s, e} i_{y, a+1, s, e+1} \\
+\left[(1+\rho)^{-1}(1+g) s r_{y, a, s}\right]\left(1-\operatorname{senr}_{y, a+1, s, e}\right) i_{y, a+1, s, e}
\end{array}
$$

where $\rho$ is the discount rate (set to 0.04 ); $g$ is the earnings growth rate (set to 0.02); and, for a person in year $y$ of age $a$, sex $s$, and level of education $e$ :

- $\quad i_{y, a, s, e}$ is average nominal lifetime earnings, in present discounted value;

- $y i_{y, a, s, e}$ is average nominal yearly earnings;

- $s r_{y, a, s}$, which is assumed to not vary by education, is the survival rate from year $y$ to year $y+1$; and

- $\quad$ senr $r_{y, a, s, e}$ is the school attendance rate.

It is assumed that nominal lifetime earnings at a maximum age (in this application, age seventyfive) are equal to zero among men and women in all years at all levels of education. With this assumption, it is possible to work backwards by age, using equation (1), to compute average nominal lifetime earnings for all combinations of year, sex, age, and education, given measures of average nominal yearly earnings, school enrollment rates, and survival rates by year, age, sex, and education.

The Jorgenson-Fraumeni model divides the life cycle into five stages (Jorgenson and Fraumeni, 1992b). In the first stage, people neither earn income $\left(y i_{y, a, s, e}=0\right)$, nor do they attend school $\left(s e n r_{y, a, s, e}=0\right)$. This period covers all ages up to age four. In the second stage, people do not earn income $\left(y i_{y, a, s, e}=0\right)$, but they may attend school $\left(\operatorname{senr}_{y, a, s, e} \geq 0\right)$. This period lasts from age five to either age thirteen (up to 1975) or fourteen (1976 and after); the post-1976 accounts constructed by Christian (2017) ends this phase at age fourteen following a change in 1980 to the minimum age for recording work experience and income in the March Current Population Survey (CPS). In the third stage, people may earn income $\left(y i_{y, a, s, e} \geq 0\right)$ or attend school $\left(\right.$ senr $_{y, a, s, e} \geq 0$ ). This period lasts from age fourteen (up to 1975) or fifteen (1976 and after) and continue through age thirty-four. In the fourth stage, people may earn income $\left(y i_{y, a, s, e} \geq 0\right)$ but do not attend school $\left(\operatorname{senr}_{y, a, s, e}=0\right)$. This period lasts from age thirty-five to age seventy-four.

human capital and other components such as market labor and to create aggregates which do not include any human capital components. 
In the fifth stage, which covers ages seventy-five and up, people do not earn income $\left(y i_{y, a, s, e}=\right.$ 0 ) or attend school $\left(\operatorname{senr}_{y, a, s, e}=0\right)$.

The approach of Jorgenson and Fraumeni (1989) includes not only market earnings, but also the value of nonmarket time outside of work, school, and personal maintenance as part of yearly (and, consequently, lifetime) earnings. Jorgenson and Fraumeni (1989) assume that time in school is assumed to be 1,300 hours per person among persons enrolled in school; time in personal maintenance is assumed to be 10 hours per day for all persons. The time per year that remains after subtracting time spent in work, school, and personal maintenance is valued at an opportunity cost equal to the wage rate multiplied by the difference between one and the marginal tax rate. The value of nonmarket time is set to zero among persons who are younger than or older than working age. Note that lifetime earnings--and all components of human capital stock and investment--can be computed in a way that includes its market component only, its nonmarket component only, or both.

The nominal stock of human capital in a given year is measured by computing the weighted sum of the population by age, sex, and education, using nominal lifetime income by age, sex, and education as a weight:

$$
h c_{y}=\sum_{a} \sum_{s} \sum_{e}\left(p_{y, a, s, e} \times i_{y, a, s, e}\right)
$$

This is equal, as mentioned above, to the expected nominal lifetime income, in present discounted value, of all individuals in an economy. The change in the nominal stock of human capital from one year to the next can be split into two components, nominal revaluation and nominal net investment:

$$
\begin{aligned}
& h c_{y}-h c_{y-1}=\sum_{a} \sum_{s} \sum_{e}\left[p_{y-1, a, s, e} \times\left(i_{y, a, s, e}-i_{y-1, a, s, e}\right)\right]+ \\
& \sum_{a} \sum_{s} \sum_{e}\left[\left(p_{y, a, s, e}-p_{y-1, a, s, e}\right) \times i_{y, a, s, e}\right]
\end{aligned}
$$

where the left-hand-side term in (3) is the change in the nominal human capital stock from year $y$-1 to $y$; the first term on the right-hand-side of (3) is nominal revaluation of the human capital stock; and the second term on the right-hand-side of (3) is nominal net investment in human capital. While (3) presents an approach in which revaluation is measured before net investment (so that human capital in year $y$-1 is revaluated using lifetime earnings in year $y$, as in Jorgenson and Fraumeni, 1989), it can be cast in such a way in which net investment is measured before revaluation.

Note that net investment is driven by changes in the size of the population and in the distribution of the population by age, sex, and education. Net investment can be divided into components associated with the different factors that change the size and distribution of the population: births, deaths, education, aging, and migration. These specific aspects of net investment are grouped more broadly in Jorgenson and Fraumeni (1989) into the component of net investment 
that increases the human capital stock (births, education, and immigration), which is denoted investment, and the component of net investment that reduces the human capital stock (deaths, aging, and emigration), which is denoted as depreciation.

As noted above, the human capital estimates up to 1975 are from Jorgenson and Fraumeni (1989), while those for 1976 and after are from a modified version of the estimates in Christian (2017), with the modifications made to more closely confirm to the Jorgenson-Fraumeni methodology. Yearly earnings are measured up to 1975 using Gollop and Jorgenson's (1980, 1983) data base of market activities (Jorgenson and Fraumeni, 1989), and in 1976 and after from estimates produced from the March demographic supplements to the CPS. Population and school enrollment is measured up to 1975 using a demographic data base produced using Census data for Jorgenson and Fraumeni (1980). For 1976 and after, school enrollment is measured using estimates produced from the October school enrollment supplements to the CPS. The October CPS is also used to measure the distribution of population by age, sex, and education for 1976 and after, but the level of population is measured using Census estimates. Survival data is drawn from life tables published by the National Center for Health Statistics (Center for Disease Control and Prevention, undated).

The human capital estimates in Christian (2017) differ in substantive ways from those in Jorgenson and Fraumeni (1989). One substantive difference is that net investment is decomposed into five components: investment from births, investment from education, depreciation from deaths, depreciation of aging, and residual net investment, which includes immigration and emigration, as well as any population discrepancies over time that result from using multiple sources of data that do not necessarily agree. We have included residual net investment as part of investment. There are many other differences between the approach in Christian (2017) and that in Jorgenson and Fraumeni (1989), but we have modified the measures in Christian (2017) to reduce these differences. These modifications include:

- Results incorporate both market and nonmarket human capital stock and investment, with nonmarket time valued as in Jorgenson and Fraumeni (1989);

- The stock of human capital is measured after investment during that year, rather than before as in Christian (2017);

- Investment is education, which is measured net of depreciation from aging while enrolled in school in Christian (2017), is measured as gross investment in education separate from depreciation of aging while in school;

- Yearly market earnings, which were measured using pre-tax wage, salary, and selfemployment income in Christian (2017), are measured instead using analogous post-tax earnings measures, and adjusted using a multiplier derived from the NIPA tables to better approximate labor compensation;

- The same multiplier is applied to nonmarket earnings, so that the opportunity cost reflects labor compensation rather than only wage, salary, and self-employment earnings; 
- $\quad$ Earnings are set to zero after age 74;

- Depreciation from aging is measured before investment in education, rather than after as in Christian (2017);

- The highest level of education is set to seventeen years of education, as in Jorgenson and Fraumeni (1989), rather than eighteen as in Christian (2017).

- The quantities underlying the contributions shown in this chapter are constructed with Törnqvist indexes as in Jorgenson and Fraumeni (1989), with the exception of the quantities underlying human saving and wealth contributions after 1975, which are constructed with Fisher indexes as in Christian (2017). ${ }^{6}$

\section{Factors Impacting on Human and Market Capital}

Among the factors impacting on human and market capital are labor force participation, the state of the economy, education, and the level of income.

Significant changes in labor force participation were highlighted in the introduction; pertinent details of labor force changes are shown in figures 1,2 , and $3 .^{7}$

There is little variation in the civilian male labor force participation rates for the 10 -year periods shown in figure 1 . The rates in the first three years - 1950, 1960, and 1970-and the next three years - 1980, 1990, and 2000 — are very similar. For the peak working ages of 25 through 54, the male civilian labor force participation rate declines monotonically starting from 1960 for all subsequent years shown. For males aged 55 and over, the rates almost monotonically decline over the seven years shown. The uptick in 2010 for older individuals and the drop for younger individuals perhaps reflected delayed retirement or difficulty finding jobs subsequent to the Great Recession, which occurred from late 2007 through mid-2009 (see table 1 for a list of recessions). The high civilian labor force participation rate in 1950 for those over 64 might reflect a shortage of male workers in the initial post-World War II era.

\footnotetext{
${ }^{6}$ The rates of growth of NIPA GDP shown in appendix table 1 are calculated from NIPA GDP quantity levels constructed with Fisher indexes.

${ }^{7}$ Fraumeni and Christian (2019) highlighted gender differences to a greater degree.
} 
Figure 1 Male labor force participation rate, percent, every ten years, 1950-2010

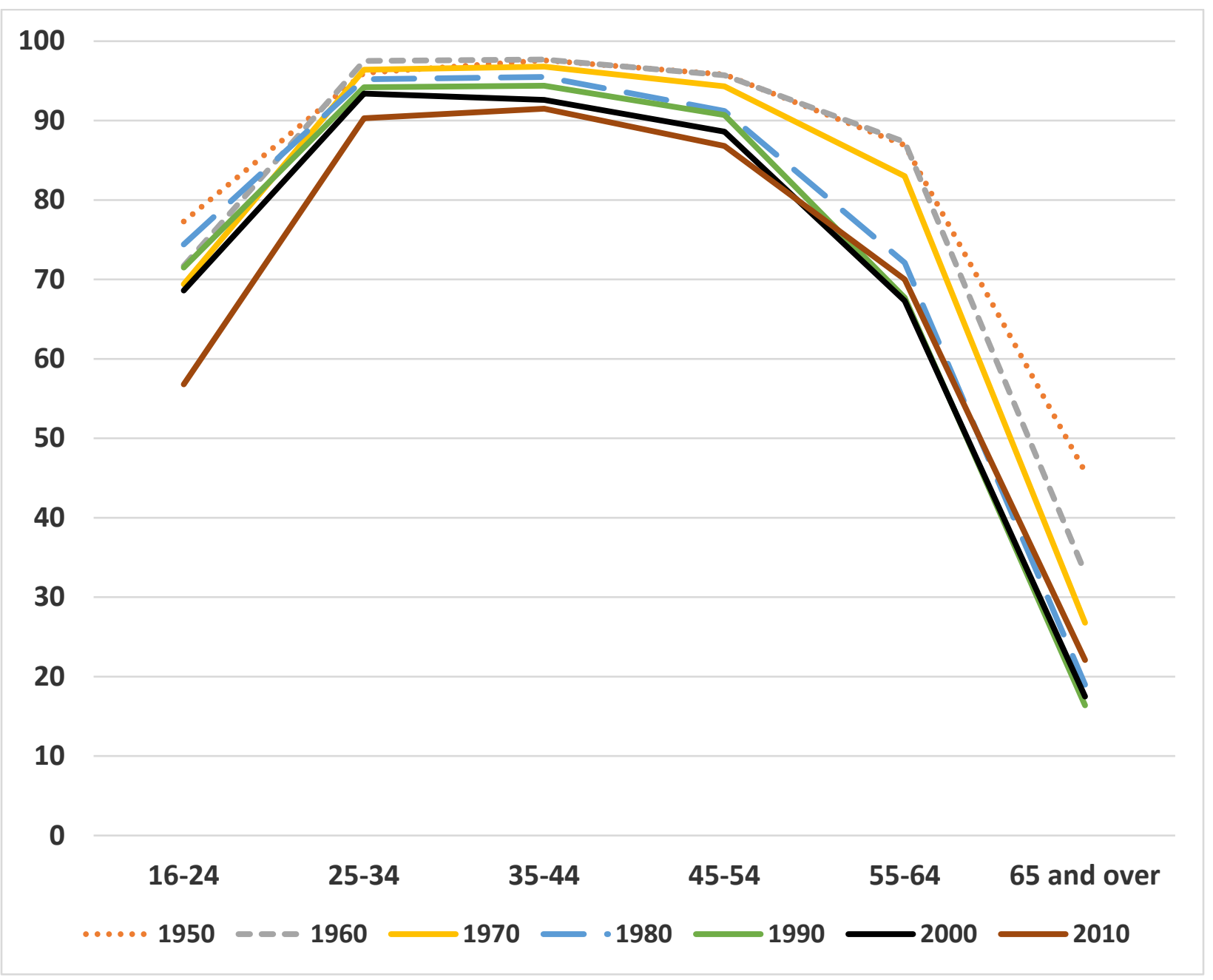

Source: Toosi (2002, 2012). 
There are important changes in the female civilian labor force participation rate (figure 2).

Table 1 List of U.S. recessions between 1940-2013, by month, year, and quarter

$\begin{array}{ll}\text { November } 1948 \text { (IV) } & \text { October } 1949 \text { (IV) } \\ \text { July } 1953 \text { (II) } & \text { May } 1954 \text { (II) } \\ \text { August } 1957 \text { (III) } & \text { April } 1958 \text { (II) } \\ \text { April } 1960 \text { (II) } & \text { February } 1961 \text { (I) } \\ \text { December 1969 (IV) } & \text { November 1970 (IV) } \\ \text { November 1973 (IV) } & \text { March 1975 (I) } \\ \text { January } 1980 \text { (I) } & \text { July } 1980 \text { (III) } \\ \text { July 1981 (III) } & \text { November 1982 (IV) } \\ \text { July } 1990 \text { (III) } & \text { March } 1991 \text { (I) } \\ \text { March 2001 (I) } & \text { November 2001 (IV) } \\ \text { December 2007 (IV) } & \text { June 2009 (II) }\end{array}$

Source: http://wwwdev.nber.org/cycles/cyclesmain.html, accessed 7/23/2019, see National Bureau of Economic Research (2019).

There are important changes in the female civilian labor force participation rate (figure 2). In 1950, 1960, and 1970 the rates decline in a classic "V" shape for those of child-bearing age. In 1950, 1960 and 1970 the "V" shape for those of child-bearing age is centered around ages 25-34; at the same time the average civilian labor force participation rate rose for females under the age of 65. The labor force participation rate among married women rose from 23 percent in 1948 to 41 percent in 1970 (figure 3). As the labor force participation rate for widowed or divorced females stayed relatively constant over the same time period (varying from 35 to at most 39 percent), the increase in labor force participation comes from married women with husbands present. As previously mentioned, the child-bearing "V" disappeared in 1980. In 1990, 2000, and 2010, increases in civilian labor force participation for prime age workers, i.e. ages 25-54, largely no longer occur, although participation among older individuals continued to increase in most cases. The uptick in participation in 2010 among women 65 or older, as is the case with males, may have been due to delayed retirements because of the Great Recession. Females aged 
25 to 64 approximately double their civilian labor force participation rates between 1950 and 2010.

Figure 2 Female labor force participation rate, percent, every ten years, 1950-2010

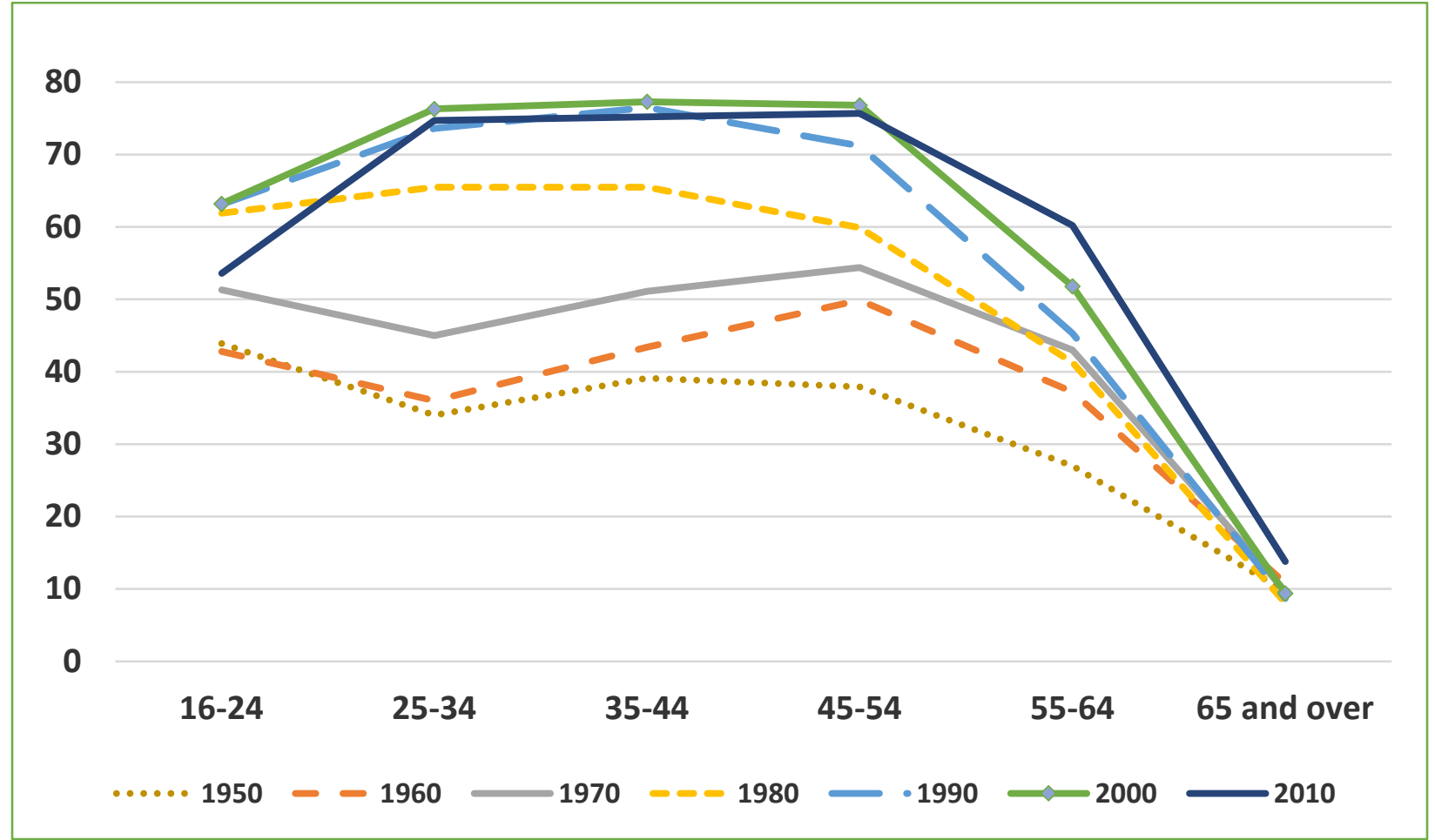

Source: Toosi (2002, 2012). 
Figure 3 Labor force participation and status of females, percent, 1948-1970

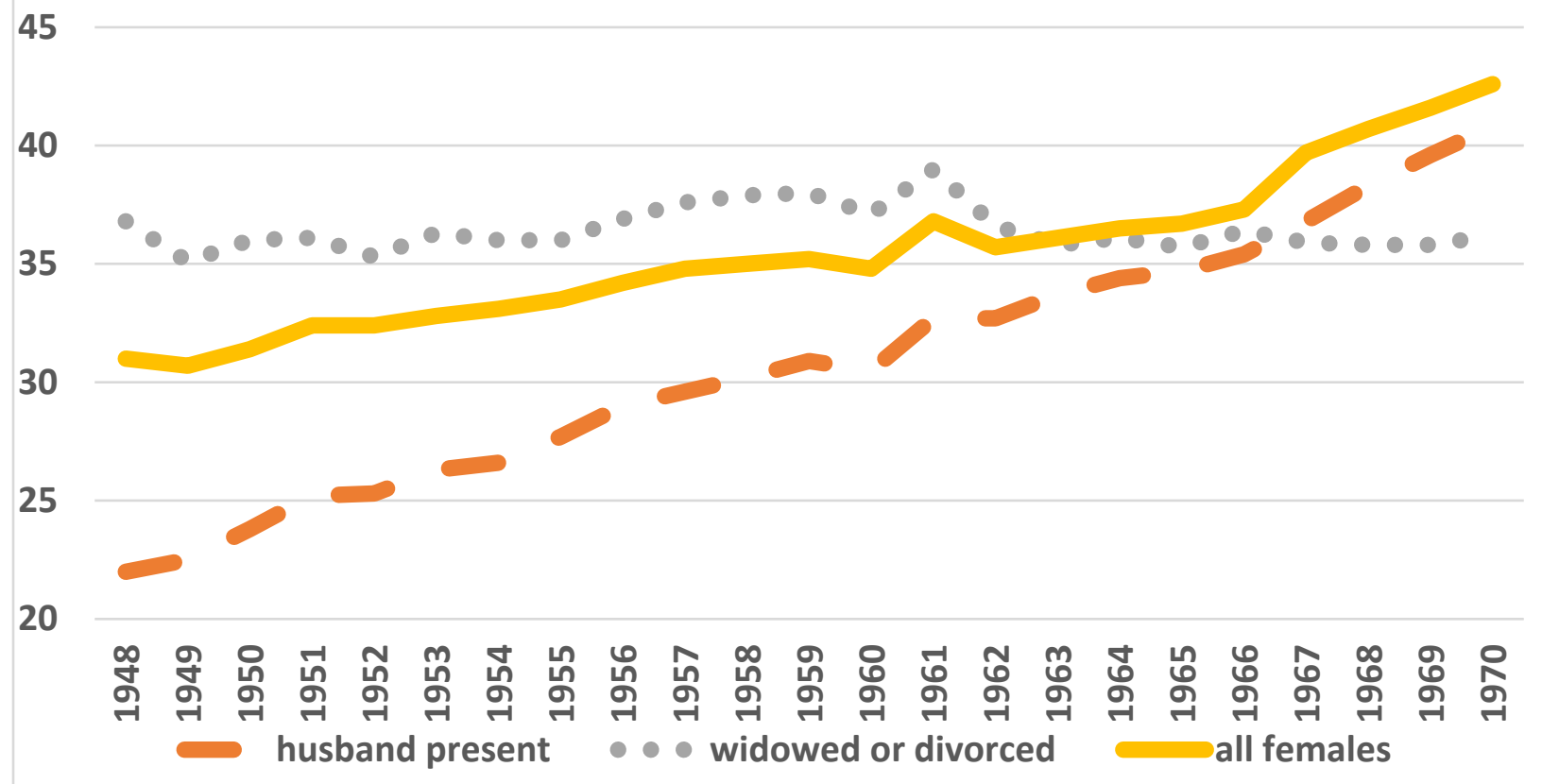

Source: https://www.census.gov/library/publications/1975/compendia/hist_stats_colonial1970.html, accessed July 22, 2019, see Census Bureau (1975).

Over the period 1950-2010, average educational attainment for both males and females substantially increases, by over 50 percent. At the beginning of the period, average educational attainment for the younger individuals, aged 25-34, is almost 50 percent higher than older individuals aged 55-64 (figure 4). By 2010 there is not much difference between educational attainment of those younger and older cohorts, and all individuals aged 15-74. These trends are very similar for males and females. However, there is a notable difference nearer to the end of the period in the tertiary education enrollment and completion rates for younger males versus younger females for those aged 25-34 (figure 5). ${ }^{8}$ By 2000, the male percentage of younger individuals who enrolled in tertiary education who complete, which started to decline by 1995, is less than the female percentage of younger individuals who enrolled in tertiary education who complete, i.e. graduate. By 2010, the female percent of those who enrolled in tertiary education who complete is 6.6 percentage points higher than the same figure for males (37.5 percent of females complete compared to 30.9 percent of males).

\footnotetext{
${ }^{8}$ Individuals who have not been in tertiary education long enough clearly have not completed their degree. The percent of individuals who have at least some years of tertiary education compared to the number who have completed is still relevant as the notable trend which begins in 1995 persists long enough for individuals to have had the time to complete.
} 
Figure 4 Barro-Lee average years of school completed every five years, ages 15-74, 25-34, and 55-64, 1950-2010

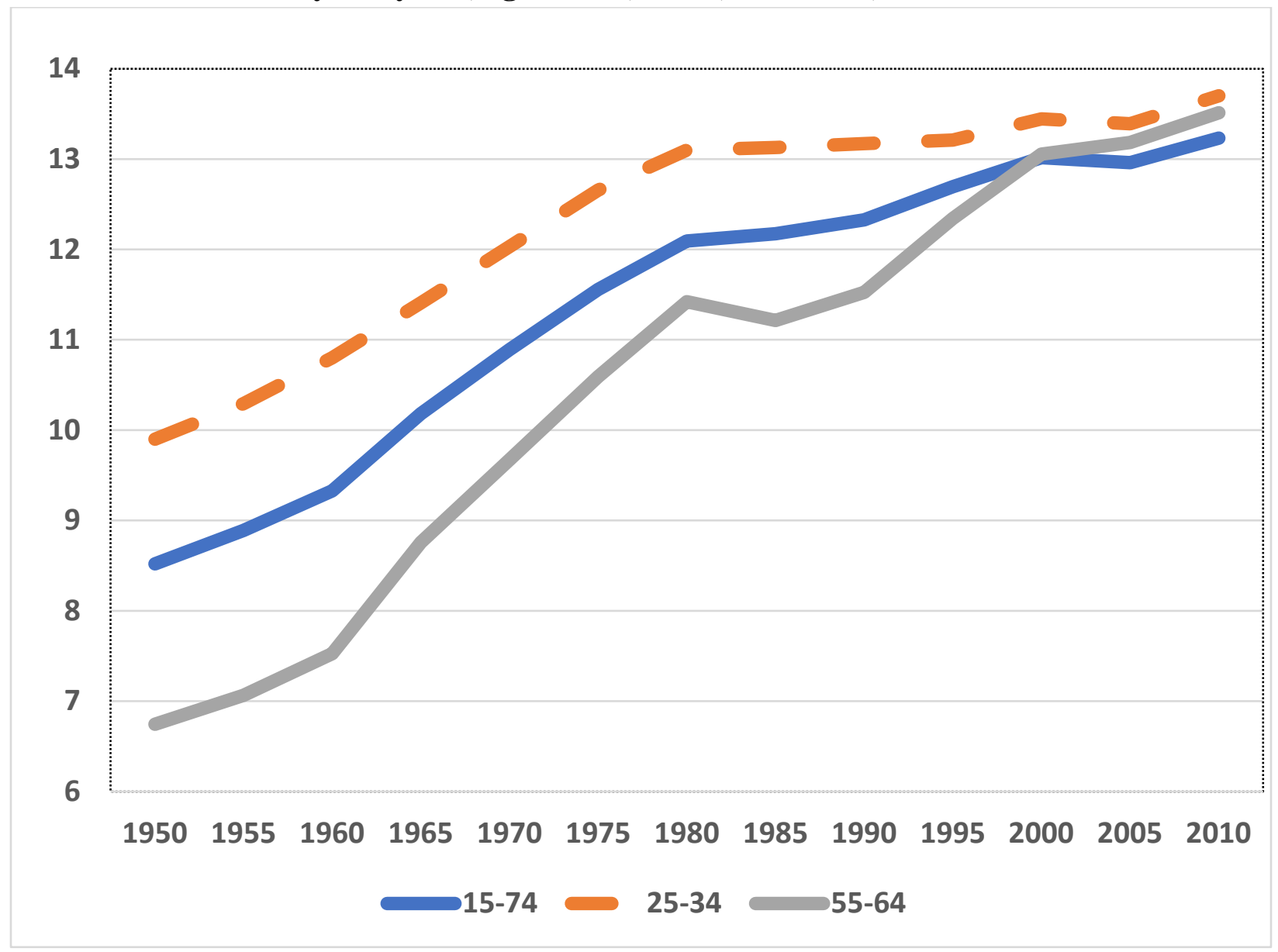

Source: Barro and Lee 2013b, see Barro and Lee 2013a for a description of the data set. 
Figure 5 Barro-Lee average tertiary years of school, percent age 25-34, every five years, 1950-2010

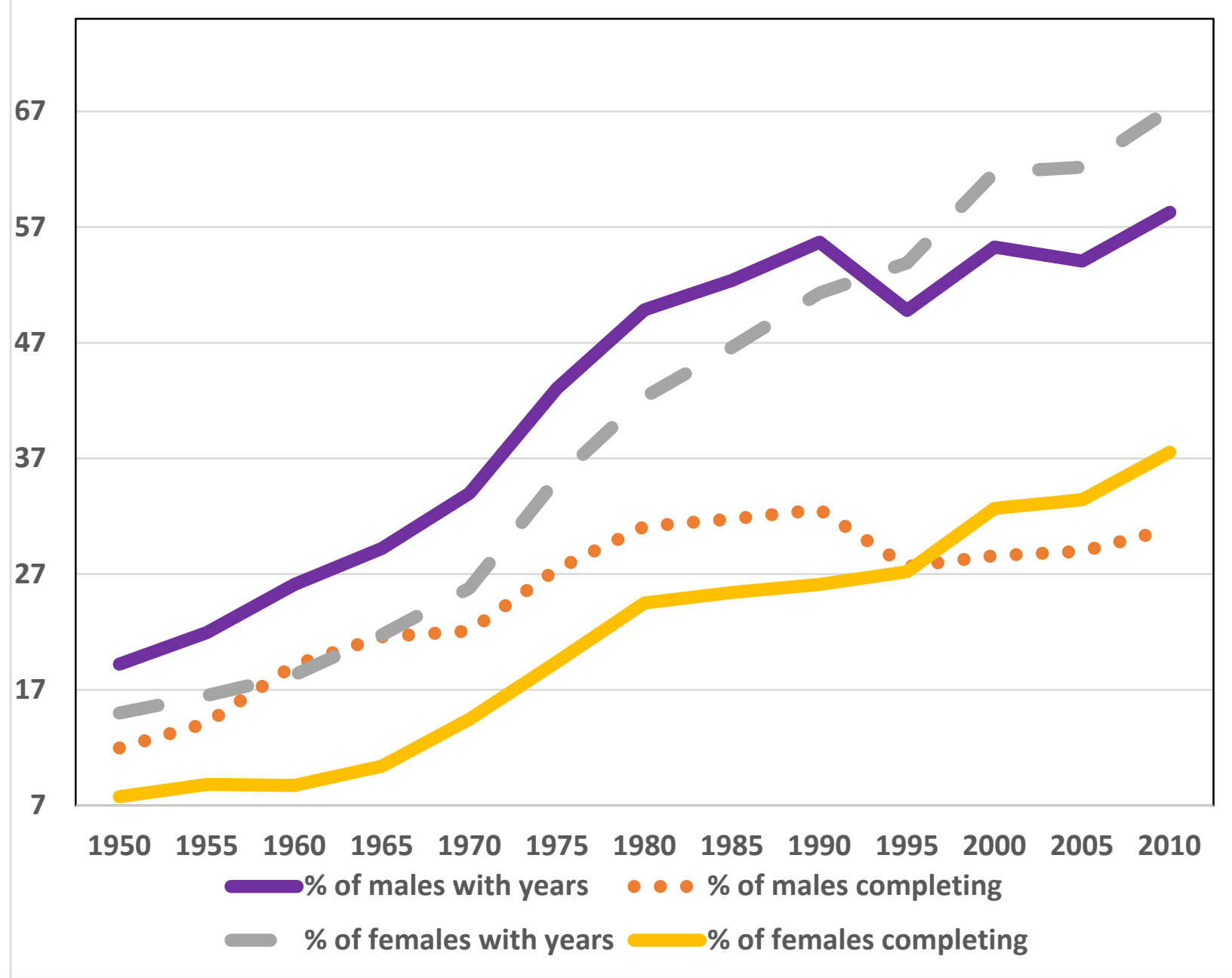

Source: Barro and Lee 2013b, see Barro and Lee 2013a for a description of the data set.

Another factor impacting human capital and the health of the economy is the level of earnings received. In 2013, mean female earnings in 2018 dollars are more than twice that in 1967; the corresponding figure for males is 40 percent. Between 1967 and 2013, mean female earnings in 2018 dollars on average grew at more than double the rate of males earnings (figure 6). One factor contributing to this difference is that mean male earnings in 2018 dollars declines during every recession that occurred after 1967; mean female earnings in 2018 dollars declines in only three of the seven recessions during that time period. ${ }^{9}$ In addition, the change in the mean female earnings exceeds that of males in two thirds of the covered years. Due in large part to the impact of the Great Recession, the mean income in 2018 dollars of both females and males is lower in 2013 than in 2006.

\footnotetext{
${ }^{9}$ See table 1 for a list of recessions.
} 
The mean earnings of females in 2018 dollars increases as a percentage of that of males between 1967 and 2013. Female mean income in 2018 dollars is less than 50 percent of that of males until 1982; this percentage does not stay consistently above 60 percent until after 2000, reaching 67 percent in 2013. However, as figure 6 shows, sometimes the female percent of mean male earnings in 2018 dollars does not always rise, for example the highest figure at 67 percent is attained in 2009. ${ }^{10}$

Figure 6 Mean earnings, percent, thousands of 2018 dollars, 1967-2013

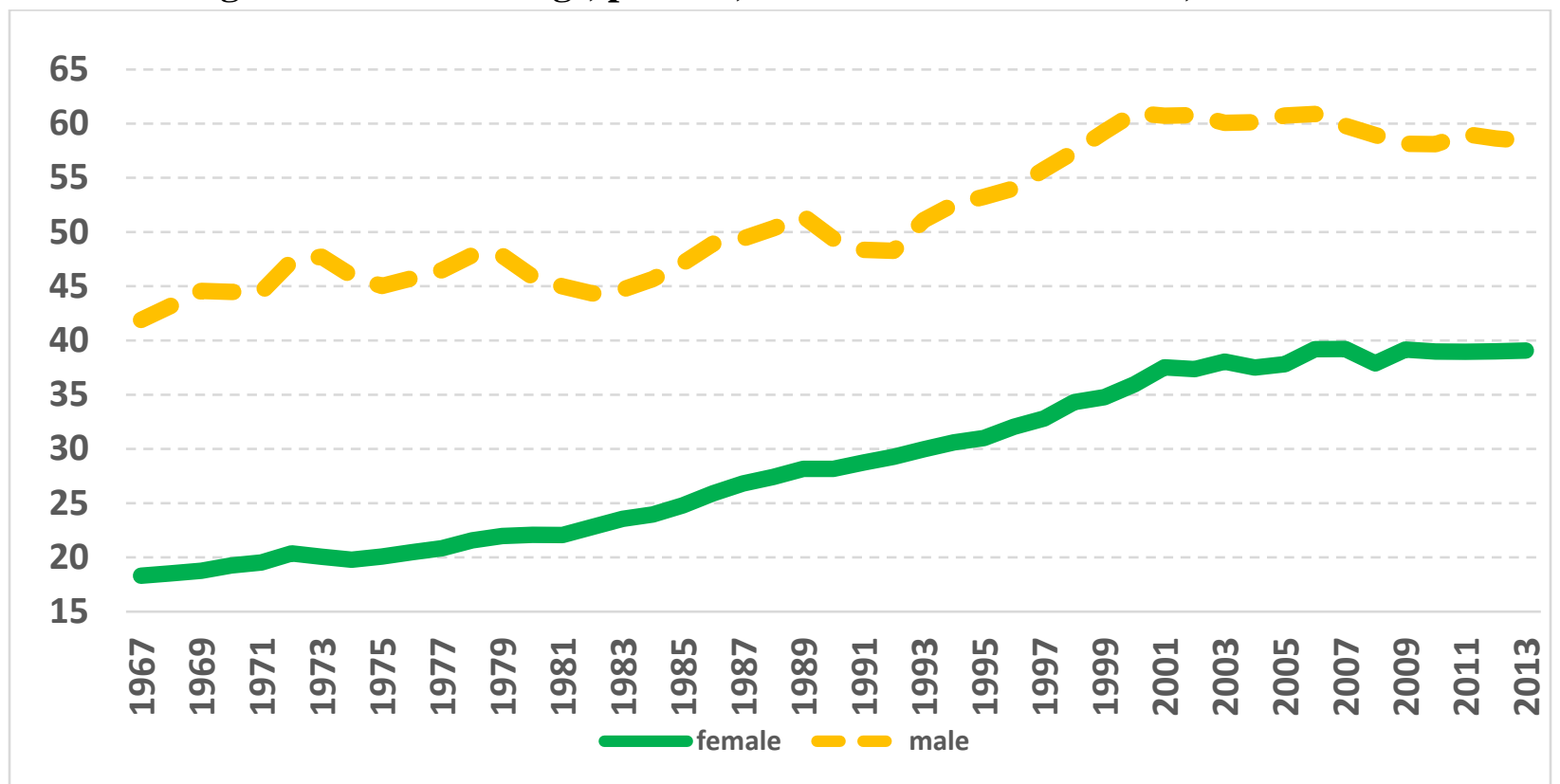

Source: https://www.census.gov/data/tables/time-series/demo/income-poverty/historical-incomepeople.html, table P-42 Work experience--All workers by mean earnings and sex: 1967 to 2018, accessed 11/15/2019. Includes those 15 years old and over beginning with March 1980, and people 14 years old and over as of March of the following year for previous years. Before 1989 earnings are for civilian workers only. Earnings in 2018 CPI-U-RS (Consumer Price Index, for all urban consumers, research series) adjusted dollars.

\section{Overview of the Accounts}

The backbone of the accounts are the five accounts summarized in figure 7. Each is outlined in detailed accounting tables with nominal values for 1948 or 1949 and for $2013 .{ }^{11}$ Together they form an expanded, complete, and integrated system for the private economy by combining

\footnotetext{
${ }^{10}$ If the percent that mean female earnings is of mean male earnings is computed with median earnings of full-time, year-round workers as in table P-40 Women's earnings as a percentage of men's earnings by race and hispanic origin: 1960 to 2018, the percents are much higher. The P-40 percents are the percents typically cited, however, in this chapter table P-42 is the basis for the discussion as all earnings impact on human capital,.

${ }^{11}$ The first year available from Jorgenson and Fraumeni (1989) for some components of the expanded gross private national capital accumulation and wealth accounts is 1949.
} 
human capital and NIPA estimates. ${ }^{12}$ The expanded accounts include a production account, incorporating data on output and input; an income and expenditures account, giving data on income, consumer expenditures and outlays, and saving; a capital accumulation and saving account, allocating saving to various types of capital formation, and a balance sheet, containing data on national wealth. The accumulation accounts are related to the wealth accounts through the accounting identity between period-to-period changes in wealth and the sum of net saving and the revaluation of assets. Of the five accounts, the expanded production account is most familiar to users as it contains a private version of GDP augmented to include the production of human capital.

\footnotetext{
${ }^{12}$ In the previous three Fraumeni co-authored papers cited earlier, the term "full” was used instead of "expanded." Since not all possible components are included in these accounts, notably those related to the environment, terminology was changed.
} 
Figure 7 Overview of the five accounts

\begin{tabular}{|c|c|}
\hline 1. EXPANDED PRODUCTION & 2. EXPANDED PRIVATE NATIONAL \\
Expanded Gross Private & LABOR \& GROSS NATIONAL \\
Domestic Product equals & PROPERTY INCOME \\
Expanded Gross Private Domestic Factor & Expanded Private National Labor Income \\
\hline
\end{tabular}

\section{EXPANDED GROSS PRIVATE NATIONAL RECEIPTS \& EXPENDITURES}

Expanded Gross Private National Income

Expanded Private National Consumer Outlays plus Expanded Gross Private National Saving

equals Expanded Private National Consumer Expenditures

Expanded Gross Private National Consumer Receipts equals Expanded Private National Consumer Expenditures

\section{EXPANDED GROSS PRIVATE NATIONAL CAPITAL ACCUMULATION}

Expanded Gross Private National Saving equals

Expanded Gross Private National Capital Formation

\section{EXPANDED PRIVATE NATIONAL WEALTH}

Private National Market Wealth equals

Private Domestic Tangible Assets plus

Net Claims on Governments and the Rest-Of-The-Word

Private National Market Wealth plus Human Wealth equals

Expanded Private National Wealth 
The production account is for the private domestic economy; the other accounts use private national economy as the conceptual basis. Government measures are included or excluded depending on which concept is being used. The private domestic concept excludes the output and inputs of the government sector. ${ }^{13}$ Compensation of government employees appears on the receipts side of the income and expenditure account as this account is based on the accounting identity that the value of consumer receipts equals the value of outlays plus saving. In general, the private national concept includes account-relevant activities that occur in the United States, but it restricts included relevant activities to those made by (such as expenditures), received by (such as income), or held by (such as wealth) private entities. To be consistent with JorgensonFraumeni human capital, the accounts take the recipients’ point of view.

Human capital appears in all five accounts in some form as human capital is fully integrated into the accounts. Each human capital component is attributed to the appropriate account construct. All human capital components in the production account are allocated to labor as part of labor services. The value of labor services provided by human capital that are not part of the value of services provided in the market are imputed. Market labor factor outlay includes an imputation for entrepreneurial labor income. In the receipts and expenditures account, the labor income arising from human capital is included as a receipt to be consistent with the inclusion of market labor compensation as a receipt; the labor income arising from human capital is identical to that which appears in the income account. On the expenditures side, the sum of all human capital components is identified as either consumption or savings. Time in household production and leisure is recorded as consumption, while the other human capital components are included in savings. ${ }^{14}$ Investment in human capital (education, births, and residual, the latter from 1976) is entered into the savings and capital accumulation parts of the account. ${ }^{15}$ The final account is the wealth account, which includes the sum of market wealth and human lifetime labor earnings.

In the analysis which follows, nominal value shares are shown in figures for selected boundary years and contributions are shown for selected periods. ${ }^{16}$

\footnotetext{
${ }^{13}$ The original accumulation paper excluded the government sector because of the complications, data requirements, and overall difficulty of including the government sector.

${ }^{14}$ Time in household production and leisure is recorded as both income and consumption as the individual implicitly receives income from himself because of the value of his time and uses this income to finance consumption.

${ }^{15}$ Human capital saving is equal to human capital investment in the accounts.

${ }^{16}$ The selected boundary years are 1948 (1949), 1973, 1995, 2000, 2007, 2009, and 2013. The selected periods are 1949-2013, 1949-2000, 1949 (1950)-1973, 1973-1995, 1995-2000, 2000-2013, 2000-2007, 2007-2009, and 2009-2013, in that order. The entire period is broken up into a period ending in 2000 and the subsequent 13 years as frequently these major subperiods look quite different; smaller subperiods are chosen for similar reasons. If the first year available from Jorgenson and Fraumeni (1987) is 1949, then nominal shares begin in 1949 and the contributions begin in 1950 (listed as 1949-1950) as contributions depend on a growth rate from the previous year to the current year.
} 
Expanded account measures from the accounting tables appear in other tables and in figures. In the first accounting table (table 2), factor outlay inputs to production are shown, where in that table labor outlay equals factor outlay minus property outlay. In that same table, expanded production (output) is built up from GNP, in other tables and figures the building blocks are consumption and investment. Tables and figures using production constructs include accounting table 2, nominal share figure 8, contribution figures 14,15 and 16 and rates of growth appendix tables 1 and 2. The second and third accounting tables (tables 3 and 4 ) use income, consumer expenditures and consumer outlays constructs. Tables and figures using these constructs include accounting tables 3 and 4, nominal share figures 9 and 10, contribution figure 18 and rates of growth appendix tables 3 and 4 . These feed into saving (accounting table 5, nominal share figures 11,12 , contribution figure 17 , and rates of growth appendix table 5) and wealth (accounting table 6, nominal share figure 13, contribution figure 19, and rates of growth appendix table 6$).{ }^{17}$

\section{Analysis of the Accounts in Nominal Dollars}

\section{IV.A. Expanded production and factor outlay}

In the first account, the production account (table 2), production and factor outlay is increased by the sum of investment in education and births and time in household production and leisure. ${ }^{18} 19$ As in the "new architecture" accounts (Jorgenson and Landefeld, 2006, 2009 and Jorgenson, 2010), the core NIPAs are modified in several ways. In the product section of the production account, to allow for integration with productivity accounts, property-type taxes are included, but some other types of taxes, such as primarily sales taxes, are excluded. Several capital services that are not in NIPA GDP are added into gross private domestic product (GPDP). These imputations, which appear in line 16 of the product section, include those for consumer durables and real estate held by institutions and producer durable equipment held by institutions. The other imputation included in line 16 of the product section is an addition to household real estate capital services as this component is undercounted in NIPA. These modifications are relatively minor in magnitude compared to NIPA GPDP.

\footnotetext{
${ }^{17}$ All rates of growth in the appendix tables are computed using logarithms.

${ }^{18}$ The residual, as previously described, is included in investment from 1976.

${ }^{19}$ All table numbers in the account tables refer to U.S. Bureau of Economic Analysis NIPA table numbers unless otherwise specified and are data published July 28, 2017.
} 


\begin{tabular}{|c|c|c|c|}
\hline \multicolumn{4}{|c|}{ Product } \\
\hline & & 1948 & 2013 \\
\hline 1 & Gross national product (table 1.7 .5 , line 4 ) & 276.3 & $16,935.8$ \\
\hline 2 & Rest-of-world gross national product (table 1.7.5, line 2 minus line 3' & 1.4 & 244.2 \\
\hline 3 & $\begin{array}{l}\text { - Compensation of government employees (table 6.2B, line } 76 \text { for 1948-97; table 6.2D, } \\
\text { line } 86 \text { for 1998-2016) }\end{array}$ & 22.9 & $1,761.6$ \\
\hline 4 & - $\quad$ Government consumption of fixed capital (table 5.1, line 17) & 10.6 & 506.5 \\
\hline 5 & Gross private domestic product (NIPA definition) & 241.4 & $14,423.5$ \\
\hline 6 & - $\quad$ Federal taxes on production and imports (table 3.5 , line 2 ) & 7.8 & 124.8 \\
\hline 7 & - $\quad$ Federal current transfer receipts from business (table 3.2, line 19 & 0.3 & 41.3 \\
\hline 8 & $+\quad$ Capital stock tax (table 3.5, line 15) & 0.0 & 0.0 \\
\hline 9 & - $\quad$ State and local taxes on production and imports (table 3.5, line 16' & 11.9 & $1,050.1$ \\
\hline 10 & - $\quad$ State and local current transfer receipts from business (table 3.3, line 18 & 0.1 & 49.5 \\
\hline 11 & $+\quad$ Business property taxes (table 3.5 , line 30 ) & 5.9 & 448.8 \\
\hline 12 & $+\quad$ Business motor vehicle licenses (table 3.5, line 31) & 0.3 & 10.2 \\
\hline 13 & Business other taxes (table 3.5 , sum of lines $32-34$ ) & 1.3 & 86.0 \\
\hline 14 & $\begin{array}{l}+\quad \text { Subsidies less current surplus of federal government enterprises (table 3.2, line } 35 \\
\text { minus line 22) }\end{array}$ & 0.8 & 69.9 \\
\hline 15 & $\begin{array}{l}+\quad \text { Subsidies less current surplus of state and local government enterprises (table 3.3, } \\
\text { line } 30 \text { minus line 21) }\end{array}$ & -0.3 & 10.3 \\
\hline 16 & Imputations for market capital services & 19.8 & 713.4 \\
\hline 17 & Gross private domestic product & 249.2 & $14,496.4$ \\
\hline 18 & Time in household production and leisure & 333.1 & $16,472.8$ \\
\hline 19 & Investment in human capital, births* & 346.6 & $10,714.1$ \\
\hline 20 & Investment in human capital, education* & 349.7 & $22,864.9$ \\
\hline 21 & Investment in human capital, residual & 0.0 & $1,461.9$ \\
\hline 22 & Expanded gross private domestic product & $1,278.5$ & $66,010.1$ \\
\hline \multicolumn{4}{|c|}{ Factor Outlay } \\
\hline 1 & $\begin{array}{l}\text { Compensation of employees, all private industries (table } 6.2 \mathrm{~B} \text { for } 1982 \text { anc } \\
\text { table } 6.2 \mathrm{D} \text { for 2009, both line } 3 \text { ) }\end{array}$ & 121.5 & $7,090.3$ \\
\hline 2 & Entrepreneurial labor income (imputation) & 28.5 & 957.8 \\
\hline 3 & $\begin{array}{l}+\quad \text { Full property outlay (line } 17 \text { from the Product account, minus lines } 1 \text { and } 2 \text { from the } \\
\text { tactor outlay account) }\end{array}$ & 99.1 & $6,448.3$ \\
\hline 4 & Gross private domestic factor outlay & 249.2 & $14,496.4$ \\
\hline 5 & Imputations for human capital from product account above (lines 18-21) & $1,029.3$ & $51,513.7$ \\
\hline 6 & Expanded gross private domestic factor outlay & $1,278.5$ & $66,010.1$ \\
\hline
\end{tabular}

Note: Totals may differ slightly from the sums due to rounding

* The split between birth and education before 1976 is imputed from a somewhat later version of the accounts presente in Jorgenson and Fraumeni (1989). Accordingly, here and in the associated graph is the only place in this paper wher this split is shown. 
Figure 8 gives a sense of the relative size of the nominal dollar expanded components for the boundary years. Education investment in human capital is always the largest component, followed typically by time in household production and leisure. The nominal value of investment in human capital comes from higher levels of education attainment (figure 4) and the higher levels of female labor force participation, particularly by 1970 by married women (figures 2 and 3). Nominal birth investment in human capital is larger than nominal GPDP only in the first two years shown. This reflects the post-World War II baby boom in 1948 and the recession in 1973 (table 1). The value of time in household production and leisure follow the trends in births until wages paid to females rose sufficiently to counteract the decrease in time as time in household production and leisure is evaluated at the opportunity cost market wage (Fraumeni and Christian, 2019, p. 524). After 2007, the nominal births share decreases and the nominal time share stays relatively constant. Beginning in 1976 a new component of expanded production exists, the residual investment in human capital, which is the impact of measured changes in the size and distribution of the population by sex, age, and education that cannot be attributed to measured births, deaths, or schooling as previously described. Nominal shares do not always sum to 1.0 because of this residual. In 2007 this residual is such a small percent of expanded production, just 0.4 percent, that it cannot be seen in the figure. 
Figure 8 Nominal share in expanded Gross Private Domestic Product, selected years

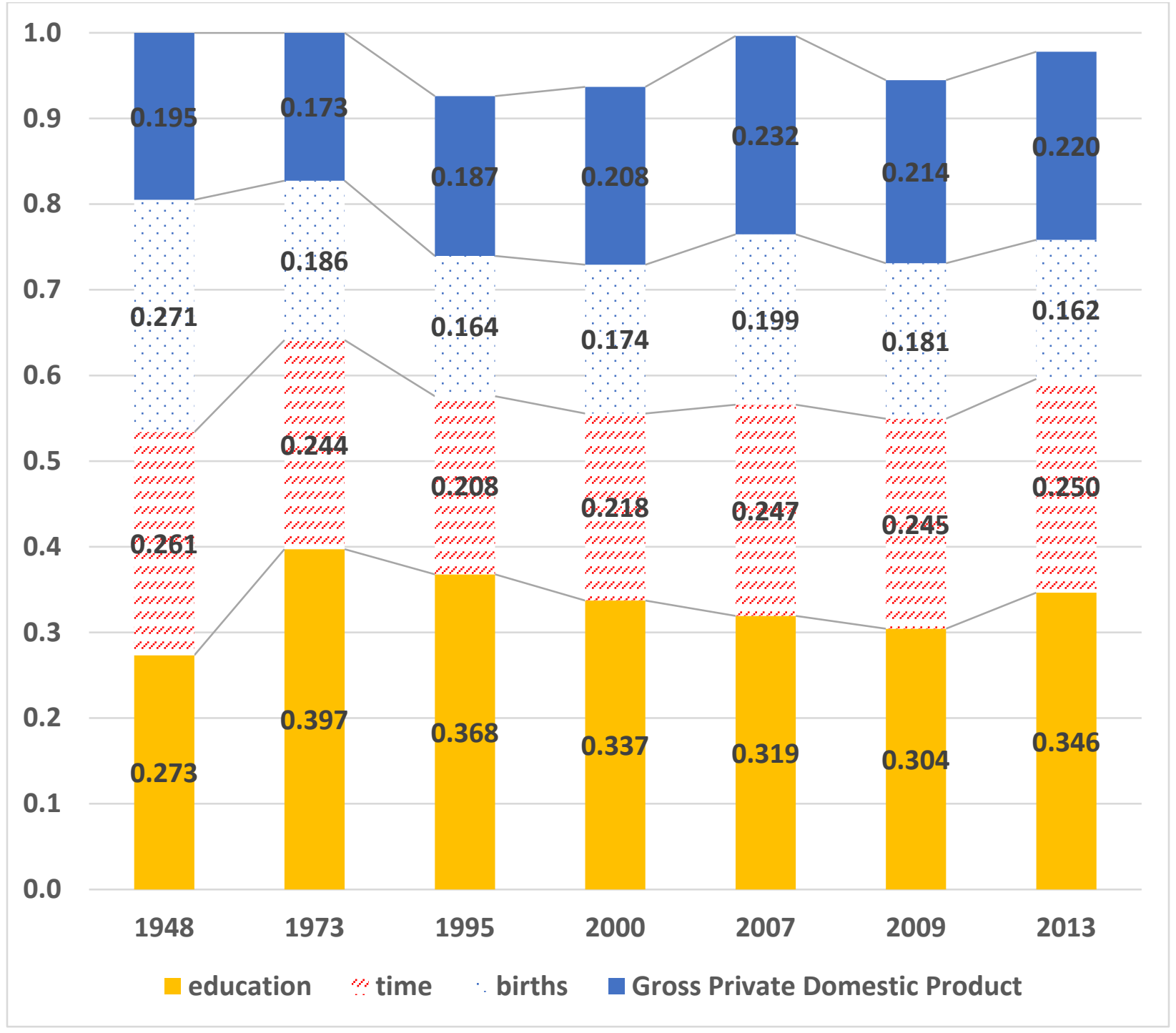




\section{IV.B. Expanded Private National Labor and Gross Private National Property Income}

The account shown in table 3 separates income into labor and property income. Property income includes only market components; only labor income has nonmarket (human capital related) expanded components. The nonmarket components are by far the largest of nominal income components (figure 9). Looking back at figure 8, it is the trends in the nominal shares of education and births investment that underlie the nonmarket labor trend between 1948 and 1973, with the birth share in expanded GPDP dropping by 31 percent and the corresponding education share increasing by 45 percent. The nominal share of nonmarket labor drops below 80 percent by 2000 (figure 9). The nominal share of market labor rose between 1995 and 2007; the share of nominal property income rose significantly between 1973 and 2009. The nominal share of residential property income in total property income fell to 31 percent in 2013 after reaching a 1948-2013 period high of 40 percent in 2009, the 2013 figure as a result of the housing crisis. The nominal share of gross private national market labor income, as a share of gross private national market income, is at its highest at 66 percent in 1948 and 1973 and at its lowest at 59 percent in 2009. The nominal share is 60 percent in 2013, very close to the 61 percent figure in 1995 and 2007. 
Table 3 Expanded private national labor and gross private national property income, United States, 1948 and 2013 (billions of dollars)

\begin{tabular}{|c|c|c|c|c|}
\hline \multicolumn{5}{|c|}{ Labor Income } \\
\hline & & & $\underline{1948}$ & $\underline{2013}$ \\
\hline 1 & & $\begin{array}{l}\text { Private domestic outlay for labor services (line } 1 \text { plus line } 2 \text { of the Factor Outlay } \\
\text { account in table 1) }\end{array}$ & 150.0 & $8,048.1$ \\
\hline 2 & + & Compensation of employees in general government (table 1.13 , line 57) & 20.3 & $1,608.5$ \\
\hline 3 & + & $\begin{array}{l}\text { Compensation of employees in government enterprises } \\
\text { (table 1.13, line } 37 \text { ) }\end{array}$ & 2.5 & 153.1 \\
\hline 4 & + & Compensation of employees, rest-of-world (table 1.13 , line 61 ) & 0.1 & -9.4 \\
\hline 5 & - & Personal income taxes attributed to labor income (imputation) & 14.1 & $1,241.8$ \\
\hline 6 & $=$ & Private national market labor income & 158.80 & $8,558.43$ \\
\hline 7 & + & Nonmarket labor income (sum of lines $18-21$ of the Product account in table 1 ) & $1,029.3$ & $51,513.7$ \\
\hline 8 & $=$ & Expanded private national labor income & $1,188.1$ & $60,072 \cdot 1$ \\
\hline \multicolumn{5}{|c|}{ Property Income } \\
\hline 1 & & Gross domestic private outlay for capital services (imputation) & 99.5 & $6,448.3$ \\
\hline 2 & + & $\begin{array}{l}\text { Capital income originating in the rest-of-world (table } 1.7 .5 \text { line } 2 \text { minus line } 3 \text { minus } \\
\text { table } 1.13 \text { line } 61 \text { ) }\end{array}$ & 1.3 & 253.6 \\
\hline 3 & + & Personal interest income (table 2.1, line 14) & 9.8 & $1,261.6$ \\
\hline 4 & - & Net interest and miscellaneous payments on assets (table 1.7.5, line 20) & 2.6 & 504.6 \\
\hline 5 & - & Personal interest payments to business (table 2.1 , line 30 ) & 1.3 & 243.9 \\
\hline 6 & + & $\begin{array}{l}\text { Investment income of social insurance funds less transfers to general government } \\
\text { (table } 3.14 \text {, line } 8 \text { plus line } 22 \text {, minus lines } 11 \text { and } 24 \text { ) }\end{array}$ & 0.4 & 94.1 \\
\hline 7 & + & Rest-of-world contributions to government social insurance (table 3.6, line 32) & 0.0 & 5.2 \\
\hline 8 & - & Corporate profits tax liability (table 3.2 line 7 plus table 3.3 line 10 ) & 12.5 & 433.6 \\
\hline 9 & - & Personal property taxes (table 3.4 , sum of lines 10 through 12 ) & 0.6 & 33.1 \\
\hline 10 & - & Business property taxes (sum of lines $11-13$ from the Product account in table 1 ) & 7.5 & 545.0 \\
\hline 11 & - & Personal income taxes attributed to property income (imputation) & 4.6 & 403.0 \\
\hline 12 & - & Federal estate and gift taxes (table 5.11, line 19) & 0.9 & 20.9 \\
\hline 13 & - & State and local estate and gift taxes (table 5.11, line 20) & 0.2 & 5.3 \\
\hline 14 & - & Net business transfer payments to foreigners (table 4.1 , line 32 minus line 15 ) & 0.0 & 20.6 \\
\hline 15 & - & Dividends received by government (table 3.1 , line 14 ) & 0.0 & 134.9 \\
\hline 16 & $=$ & Gross private national market property income & 80.9 & $5,717.9$ \\
\hline
\end{tabular}

Note: Totals may differ slightly from the sums due to rounding. 
Figure 9 Nominal share in expanded income, selected years

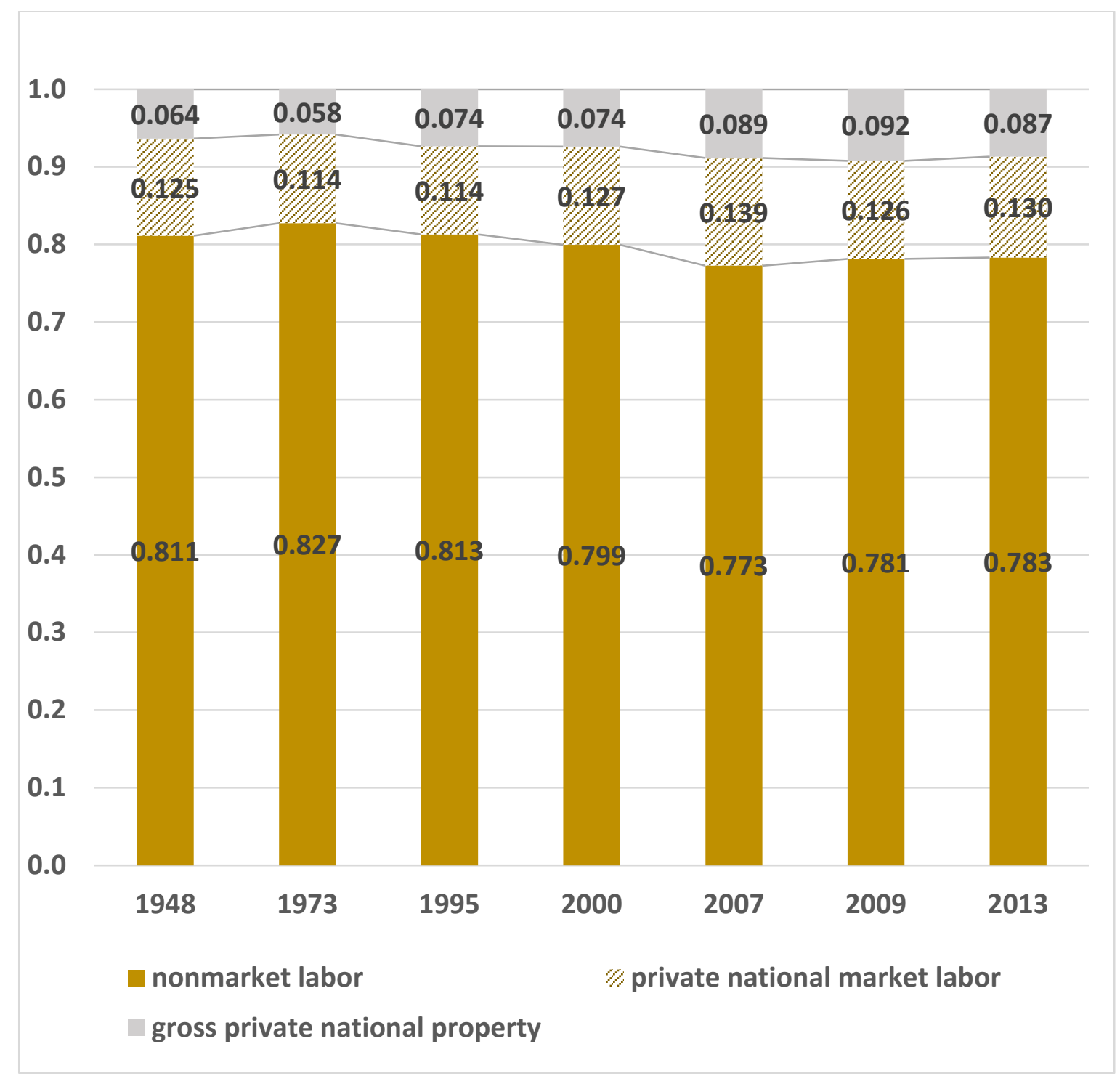

\section{IV.C. Expanded Gross Private National Consumer Expenditures}

The main interest in the third account listed in table 4 is in the expenditure section of this account. Expanded gross private national consumer receipts are only very slightly larger than expanded gross private national income, accounting for more than one percent of it for only three years. Since expanded gross private national income is split into its two component partsproperty income and expanded labor income in table 3-only the expenditure section of the third account is shown in table 4. This expenditure section splits expenditures into market consumer outlays (lines 4 plus 7 plus 8 ) versus saving (line 10). The fourth accounting table, table 5, further splits saving into gross private national saving and human capital saving; this split is incorporated into figure 10. After falling between 1948 and 1995, the nominal share of 
consumption outlays in total outlays including nonmarket outlays rose 7.5 percentage points between 1995 and 2007, amounting to about 40 percent of the total for the last three years shown. Nominal gross private national (market) saving is a small percentage of expanded private national expenditures and varies by at most .7 percentage points. The percentage of nominal market saving increases between 1948 and 1973, subsequently declining between 1973 and 2000, increasing again between 2000 and 2009, before settling to 6.3 percent in 2013. As the percentage of nominal market saving is very small compared to human capital saving, the fluctuations in total saving and total consumption arise mainly from fluctuations in the nominal share of human capital saving in expanded private national saving. Nominal human capital saving is about 90 percent of total saving for all years shown; accordingly, when the total nominal saving share of total private national expenditures increases (decreases), the total nominal consumption share of total private national expenditures decreases (increases). 
Table 4 Expanded gross private national consumer expenditures, United States, 1948 and 2013 (billions of dollars)

\begin{tabular}{|c|c|c|c|c|}
\hline \multicolumn{5}{|c|}{ Expenditures } \\
\hline & & & $\underline{1948}$ & $\underline{2013}$ \\
\hline 1 & & Personal consumption expenditures (table 1.1.5, line 2 ) & 175.0 & $11,361.2$ \\
\hline 2 & - & Personal consumption expenditures, durable goods (table 1.1.5, line 4) & 24.5 & $1,241.7$ \\
\hline 3 & + & Imputation for market capital services (line 16 from the Product account of table 7.2) & 19.8 & 713.4 \\
\hline 4 & $=$ & Private national consumption expenditure & 170.3 & $10,832.9$ \\
\hline 5 & + & Consumption of nonmarket goods and services (line 18 from the Product account of table 7.2) & 333.1 & $16,472.8$ \\
\hline 6 & $=$ & Expanded private national consumption expenditure & 503.4 & $27,305.7$ \\
\hline 7 & + & Personal transfer payments to foreigners (table 2.1, line 33) & 0.7 & 77.3 \\
\hline 8 & + & Current transfer receipts from persons (table 3.1, line 17) & 0.3 & 93.4 \\
\hline 9 & $=$ & Expanded private national consumer outlays & 504.4 & $27,476.4$ \\
\hline 10 & + & Expanded gross private national saving (line 15 from the Saving account of table 7.5) & 771.9 & $39,228.6$ \\
\hline 11 & $=$ & Expanded gross private national expenditures & $1,276.4$ & $66,705.0$ \\
\hline
\end{tabular}

Note: Totals may differ slightly from the sums due to rounding. 
Figure 10 Nominal share in expanded consumption, selected years

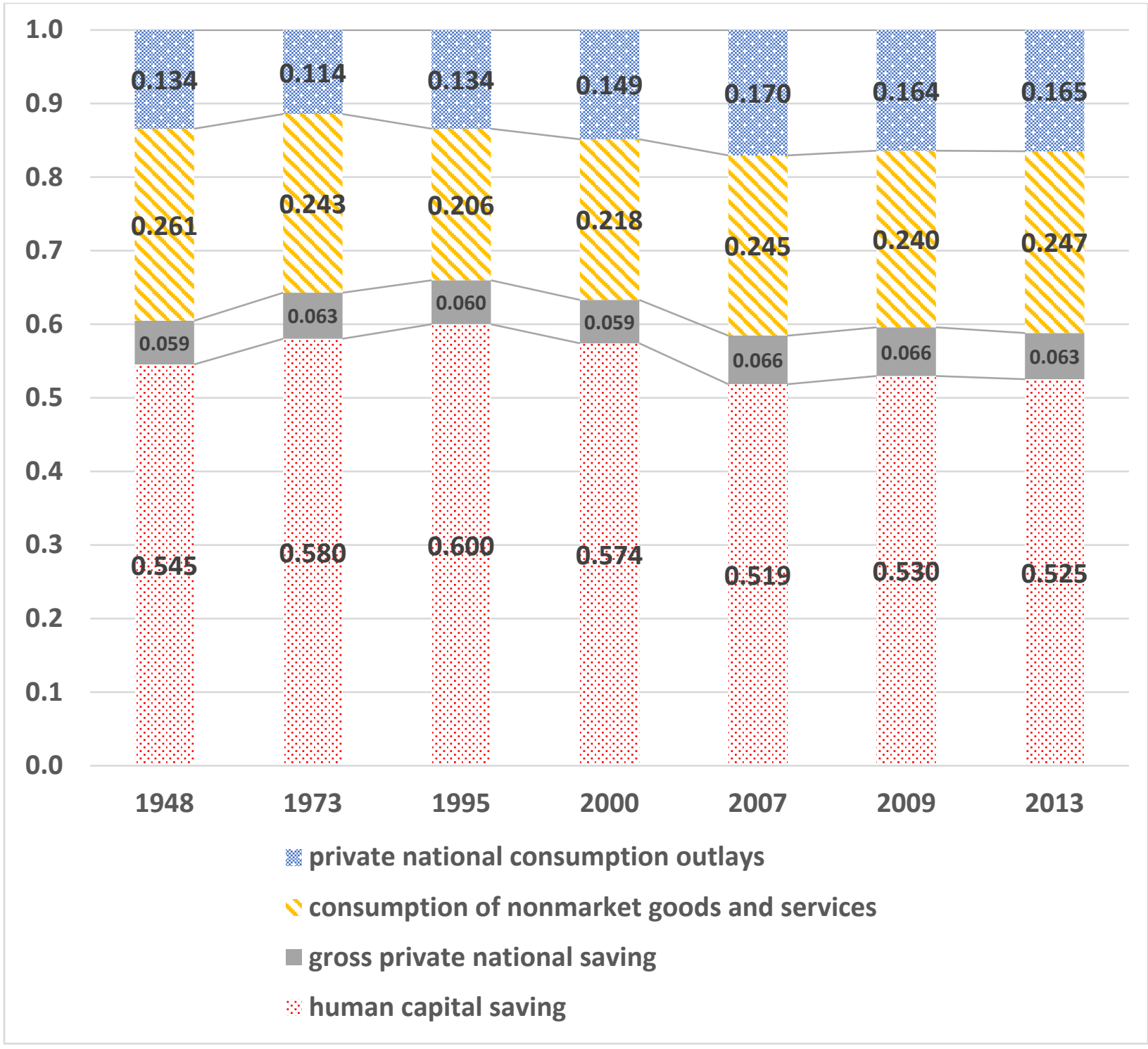

\section{IV.D. Expanded Gross Private National Capital Saving}

The saving section of this accounting table (table 5) shows how change in expanded private national wealth is derived from expanded gross private national saving. Since expanded private national capital accumulation is always equal to private national saving, only the saving section of the account is shown. ${ }^{20}$ There is a great deal of variation in the nominal shares of gross private national saving, human capital saving, private national saving, revaluation, and depreciation in change in expanded private national wealth (figure 11). In this table and in the associated figures, 1949 is the first year shown instead of 1948 because Jorgenson and Fraumeni (1989) published estimates for saving and wealth starting in 1949. Recall that between 1948 and 1973, the

\footnotetext{
${ }^{20}$ Similarly, human capital accumulation is always equal to human capital saving.
} 
nominal share of births in GPDP decreases and the nominal share of education investment in GPDP increases by enough to offset the decrease in the nominal birth share (refer back to figure 8), reflecting the end of the post-World War II baby boom and the continuing increase in the average number of years of school completed, particularly for younger females (figures 4 and 5). This is also true between 1949 and 1973. In 1973, the nominal share of human capital saving in change in expanded private wealth decreases in spite of this fact because the increase in the nominal value of the change in private national wealth is more than a third greater than the increase in education investment between 1949 and 1973; this is due to the significant size of revaluation. The nominal value of revaluation increases tenfold between 1949 and 1973, 50 percent greater than the rate of increase in education investment, and the share of nominal depreciation in change in expanded saving is substantially less negative (figure 11). 
Table 5 Expanded gross private national saving, United States, 1949 and 2013 (billions of dollars)

\section{Saving}

\begin{tabular}{|c|c|c|c|c|}
\hline \multicolumn{5}{|c|}{ Saving } \\
\hline & & & $\underline{1949}$ & $\underline{2013}$ \\
\hline \multirow[t]{2}{*}{1} & & Gross private saving NIPA (table 5.1, line 43) & 47.9 & $3,378.3$ \\
\hline & & Personal consumption expenditures, durable goods (line 2 of the Expenditures account in table & & \\
\hline 2 & + & 3) & 26.6 & $1,241.7$ \\
\hline 3 & + & Surplus, social insurance funds (table 3.14 , line 1 plus line 16 minus lines 10 and 23) & 1.5 & -286.7 \\
\hline 4 & + & Statistical discrepancy (table 5.1, line 42) & 1.7 & -137.9 \\
\hline \multirow[t]{2}{*}{5} & - & Taxes on wealth (Estate and gift taxes, table 5.11, line 18) & 0.9 & 26.1 \\
\hline & & Capital transfer payments to persons and financial stablization payments (table 5.11 , sum of & & \\
\hline 6 & + & lines 12-14) & 0.0 & 6.1 \\
\hline 7 & + & Other capital transfers paid to business (table 5.11, line 13 ) & 0.0 & 5.7 \\
\hline 8 & + & Capital transfers paid, Federal disaster-related insurance benefits (table 5.11, line 11 ) & 0.0 & 0.00 \\
\hline \multirow[t]{2}{*}{9} & + & Capital transfers paid, State and local disaster-related insurance benefits (table 5.11, line 17) & 0.0 & 0.00 \\
\hline & & Capital transfers received, State and local disaster-related insurance benefits (table 5.11, line & & \\
\hline 10 & - & 39) & 0.0 & 0.00 \\
\hline 11 & + & Federal net purchases of nonproduced (table 3.2, line 46) & 0.0 & -2.4 \\
\hline 12 & + & State and local net purchases of nonproduced assets(table 3.3 , line 41 ) & 0.2 & 9.0 \\
\hline 13 & $=$ & $\begin{array}{l}\text { Gross private national saving } \\
\text { Human capital saving ( } 1949 \text { authors' calculations, } 2013 \text { sum of lines } 19-21 \text { of the Product }\end{array}$ & 77.0 & $4,187.7$ \\
\hline 14 & + & account in table 7.2) & 742.1 & $35,040.9$ \\
\hline 15 & $=$ & Expanded gross private national saving & 819.1 & $39,228.6$ \\
\hline 16 & - & Depreciation* & 625.9 & $34,899.3$ \\
\hline 17 & $=$ & Net private national saving & 193.1 & $4,329.3$ \\
\hline 18 & + & Revaluation* & 823.6 & $18,709.6$ \\
\hline 19 & $=$ & Change in expanded private national wealth & $1,016.7$ & $23,038.9$ \\
\hline
\end{tabular}

Note: Totals may differ slightly from the sums due to rounding. 
Figure 11 Nominal share in change in expanded saving, selected years

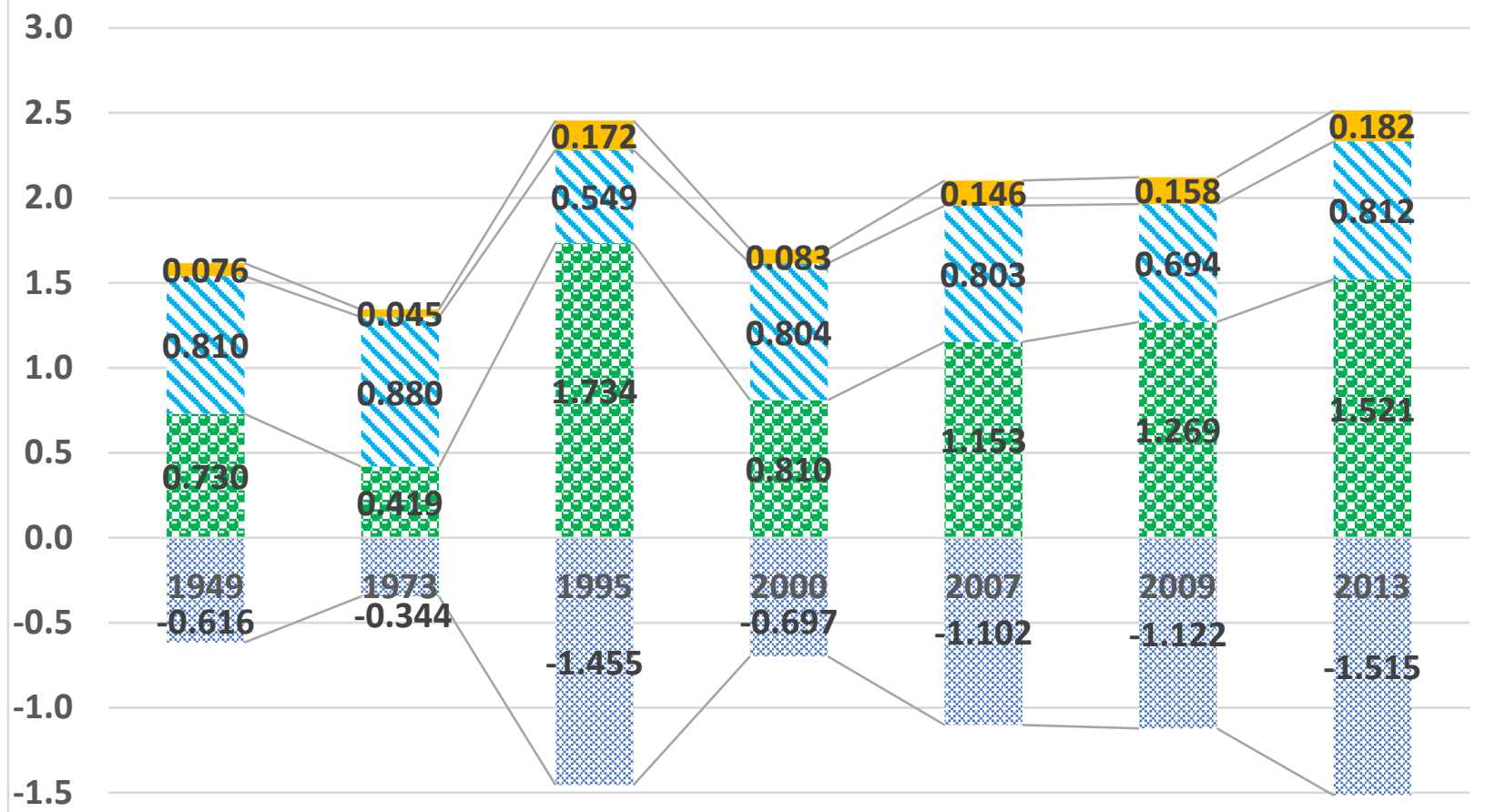

\section{-2.0 depreciation human capital saving $\times$ revaluation gross private national saving}

Since revaluation and depreciation can be broken out into human capital and market components beginning in 1976, further analysis refers to figure 12. In this figure for years in which there is data, the sum of the nominal share of human capital revaluation and private national (market) revaluation and the sum of the nominal share of human capital depreciation and private national (market) depreciation are identical to the total revaluation and depreciation shares shown in figure $11 .{ }^{21}$ In all years, the absolute value magnitude of the nominal share of human capital depreciation is at least three-quarters of the nominal share of human capital saving. In 2007 and 2013, the ratios of the absolute values of the nominal shares of human capital depreciation to human capital saving are notably higher than in other years. In 1995 and 2013 human capital saving and human capital depreciation play a larger role in change in expanded private national wealth than in other years. By 2000, the pace of increase in average number of years completed and the difference between the average years of school completed by younger individuals, those 25-34, and older individuals, those aged 55-64, had narrowed considerably (figure 4). Beginning in 2000, the absolute value magnitude of both the nominal share of human capital saving and depreciation in change in expanded private national wealth increase. In 2007 and 2009, the

\footnotetext{
${ }^{21}$ Human capital depreciation includes the change in the present discounted value of lifetime earnings as people age. When an individual ages as retirement is closer, the present discounted value of lifetime earnings normally decreases as there are fewer years left to earn. When an individual retires, reaches 75 , or dies, the present discounted value becomes zero.
} 
nominal share of private national revaluation is negative, reflecting the state of the economy (table 1). 
Figure 12 Nominal share in change in private national wealth, selected years

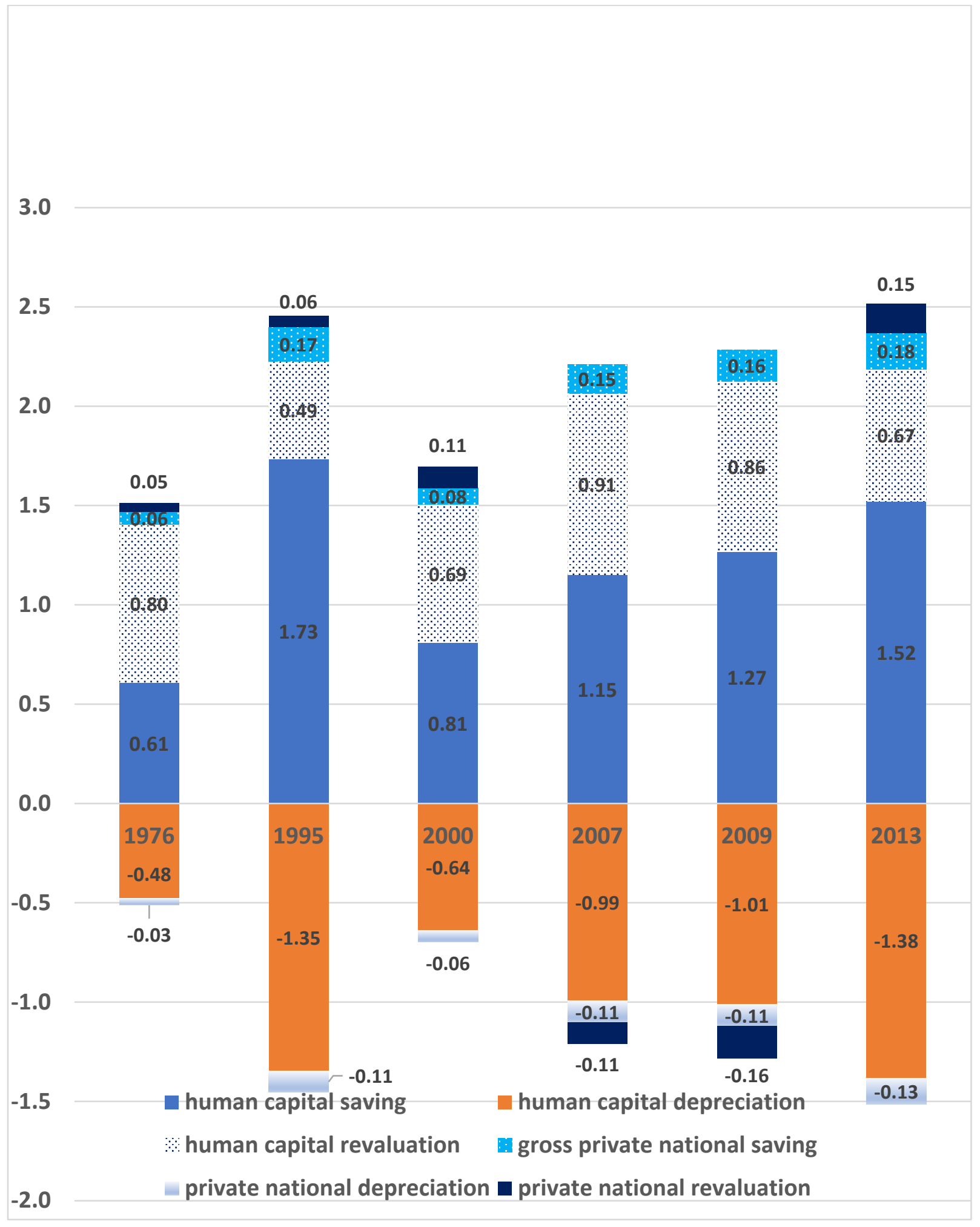




\section{IV.E. Expanded Wealth}

The final set of accounts is the wealth account (table 6). The nominal share of human wealth in expanded private national wealth is always at least 90 percent, while the nominal share of net claims on government and the rest-of-world is always very small (figure 13). Human wealth, a stock, fluctuates less than human capital investment as the latter is an annual change. As previously shown in figure 8, as the nominal shares of both birth and education investment in GPDP decline between 1973 and 1995, the nominal share of human wealth in expanded private national wealth declines. However, it is not surprising to see a smaller decline in the share of human wealth in expanded private national wealth than in the share of birth and education investment in GDP between the same two years. The second largest decline in the nominal human wealth share, which occurs between 2000 and 2007, reflects the slower pace of education investment noted earlier, as well as the continuing drop in the percentage of males with years of tertiary education who completed (figure 5). The temporary recovery of the nominal share of human wealth in 2009 is due to the percentages of individuals aged 18 to 24 enrolled in a postsecondary degree-granting institution increasing substantially from 2006 to 2009 (Fraumeni and Christian, 2019, p. 509 ). 
Table 6 Expanded private national wealth, United States, 1949 and 2013 (billions of current dollars)

\begin{tabular}{|c|c|c|c|c|c|c|c|c|c|}
\hline & & & & & & \multicolumn{2}{|c|}{$\underline{1949}$} & \multicolumn{2}{|c|}{2013} \\
\hline 1 & & \multicolumn{4}{|c|}{ Private domestic tangible assets } & 907 & & 63,336 & \\
\hline & & \multicolumn{4}{|c|}{ Net claims on federal, state, and local governments } & 233 & & 12,962 & \\
\hline \multirow[t]{5}{*}{2} & + & a. & \multicolumn{3}{|c|}{ Federal, monetary } & 46 & & 3,375 & \multirow[b]{2}{*}{74} \\
\hline & & & (i) & + & Vault cash of commercial banks $^{a}$ & & 2 & & \\
\hline & & & (ii) & + & Member bank reserves ${ }^{a}$ & & 17 & & 2,249 \\
\hline & & & (iii) & + & Currency outside banks ${ }^{a}$ & & 26 & & 1,168 \\
\hline & & & (iv) & + & Par to market value adjustment (imputation) & & 2 & & -115 \\
\hline \multirow[t]{9}{*}{3} & + & \multicolumn{4}{|c|}{ Federal, nonmonetary } & 181 & & 7,472 & \\
\hline & & & (i) & + & U.S. government total liabilities ${ }^{a}$ & & 236 & & 16,100 \\
\hline & & & (ii) & - & U.S. government financial assets ${ }^{a}$ & & 33 & & 1,717 \\
\hline & & & (iii) & + & Net liabilities, federally-sponsored credit agencies ${ }^{a}$ & & 0 & & -46 \\
\hline & & & (iv) & + & Assets of social insurance funds ${ }^{b}$ & & 20 & & 3,073 \\
\hline & & & (v) & - & U.S. government liabilities to rest-of-world ${ }^{c}$ & & 0 & & 6,420 \\
\hline & & & (vi) & + & U.S. government credits and claims abroad ${ }^{c}$ & & -2 & & 227 \\
\hline & & & (vii) & - & Monetary liabilities $^{a}$ & & 44 & & 3,490 \\
\hline & & & (viii) & + & Par to market value adjustment (imputation) & & 6 & & -254 \\
\hline \multirow[t]{4}{*}{4} & + & \multicolumn{4}{|c|}{ State and local } & 6 & & 2,114 & \\
\hline & & & (i) & + & State and local total liabilities ${ }^{a}$ & & 23 & & 5,287 \\
\hline & & & (ii) & - & State and local financial assets ${ }^{a}$ & & 16 & & 2,928 \\
\hline & & & (iii) & + & Par to market value adjustment (imputation) & & 0 & & -244 \\
\hline \multirow[t]{3}{*}{5} & + & \multicolumn{4}{|c|}{ Net claims on the rest-of-world } & 18 & & 1,829 & \\
\hline & & a. & & \multicolumn{2}{|c|}{ Private U.S. assets and investments abroad ${ }^{c}$} & & 28 & & 16,647 \\
\hline & & b. & - & \multicolumn{2}{|c|}{ Private U.S. liabilities to foreigners ${ }^{c}$} & & 10 & & 14,818 \\
\hline 6 & $=$ & \multicolumn{4}{|c|}{ Private national nonhuman wealth } & 1,392 & & 91,088 & \\
\hline 7 & + & \multicolumn{4}{|c|}{ Private national human wealth } & 18,249 & & 785,905 & \\
\hline 8 & $=$ & \multicolumn{4}{|c|}{ Full private national wealth } & 19,641 & & 876,993 & \\
\hline
\end{tabular}

Note: Totals may differ slightly from the sums due to rounding.

${ }^{a}$ Board of Governors of the Federal Reserve System, Flow of Funds Accounts, various issues.

${ }^{b}$ U. S. Department of Treasury, Treasury Bulletin, February issues and December Monthly Treasury Statement Table 6, Schedule D.

c "The International Investment Position of the United States," Survey of Current Business, various issues and the Integrated Macro Accounts for the United States, at https://www.bea.gov/data/special-topics/integrated-macroeconomic-accounts. 
Figure 13 Nominal share in expanded wealth selected years

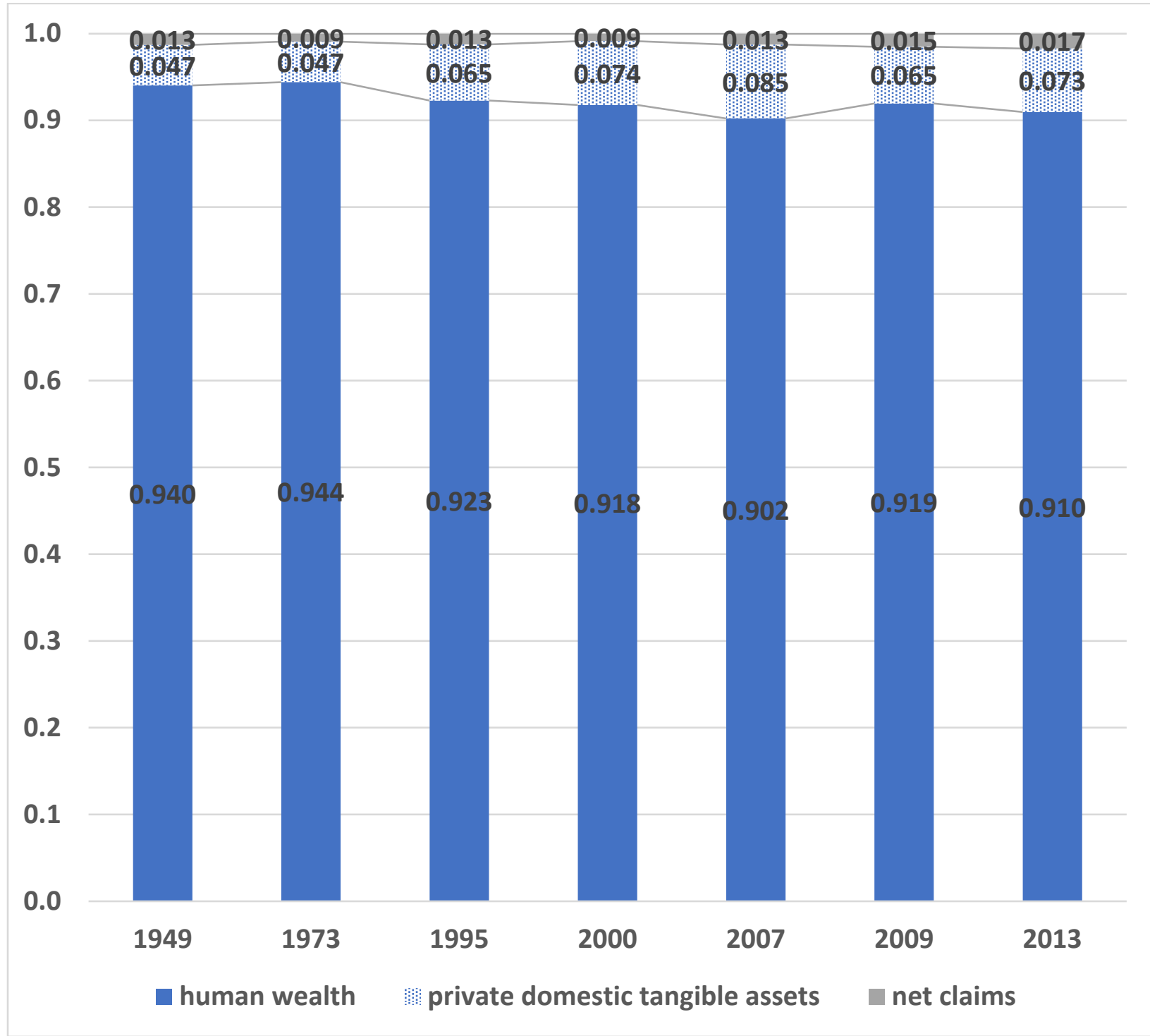

\section{Analysis of Contributions and Rates of Growths}

Contributions (figures 14, 15, 16, 17, 18, and 19) are weighted rates of growth, where the weights are average nominal shares and the rates of growth are the rates of growth of the quantities. 


\section{V.A. Contributions to Expanded Gross Private Domestic Product and Economic Growth and Rates of Growth}

This contribution figure is presented without (figure 14) and with human capital (figure 15) components for comparison purposes. The total growth rate with human capital is always less than the total growth rate without human capital. As figure 8 shows, nominal human capital components are always very large relative to GPDP. Growth in human capital components depends upon population and wage or income growth and increasing levels of education, as reflected in lifetime income weights. These all grow slowly relative to GDP (see appendix table 1). GDP grows at an average rate of 3.2 percent per year between 1949 and 2013. The progress in raising the average number of years in school for the population aged 15 to 74 (figure 4) is notable, but the average increase per year between 1950 and 2010 is 0.7 percent. The average population increase per year between 1949 and 2013 is 1.2 percent per year (appendix table 1). Female mean earnings in 2018 dollars grows at an average annual rate of 1.6 percent per year between 1967 and 2013; the corresponding figure for males is .7 percent per year (figure 6). In this chapter, human capital depends on lifetime earnings. Lifetime earnings estimates assume a real labor earnings growth rate of two percent per year across the demographic groups following Jorgenson and Fraumeni (1989), which is fairly high, but the impact of this on human capital growth is tempered as future earnings are discounted to the present value. Accordingly, for the first major subperiod, 1949-2000, the total growth rate without human capital is almost double that of the version with human capital, although in 1995-2000 it is three times as large.

In addition, the absolute value magnitude of multifactor productivity change is always substantially less in the version with human capital than in the version without human capital as it is implicitly assumed that there is no multifactor productivity associated with any of the human capital components. The human capital components quantities on the output side are identical to those on the input side of the accounts. The absolute value magnitude of multifactor productivity change without human capital is usually around five times or more that of the version with human capital. 
Figure 14 Contributions to expanded Gross Private Domestic Product and economic growth without human capital, percentage, 1949-2013

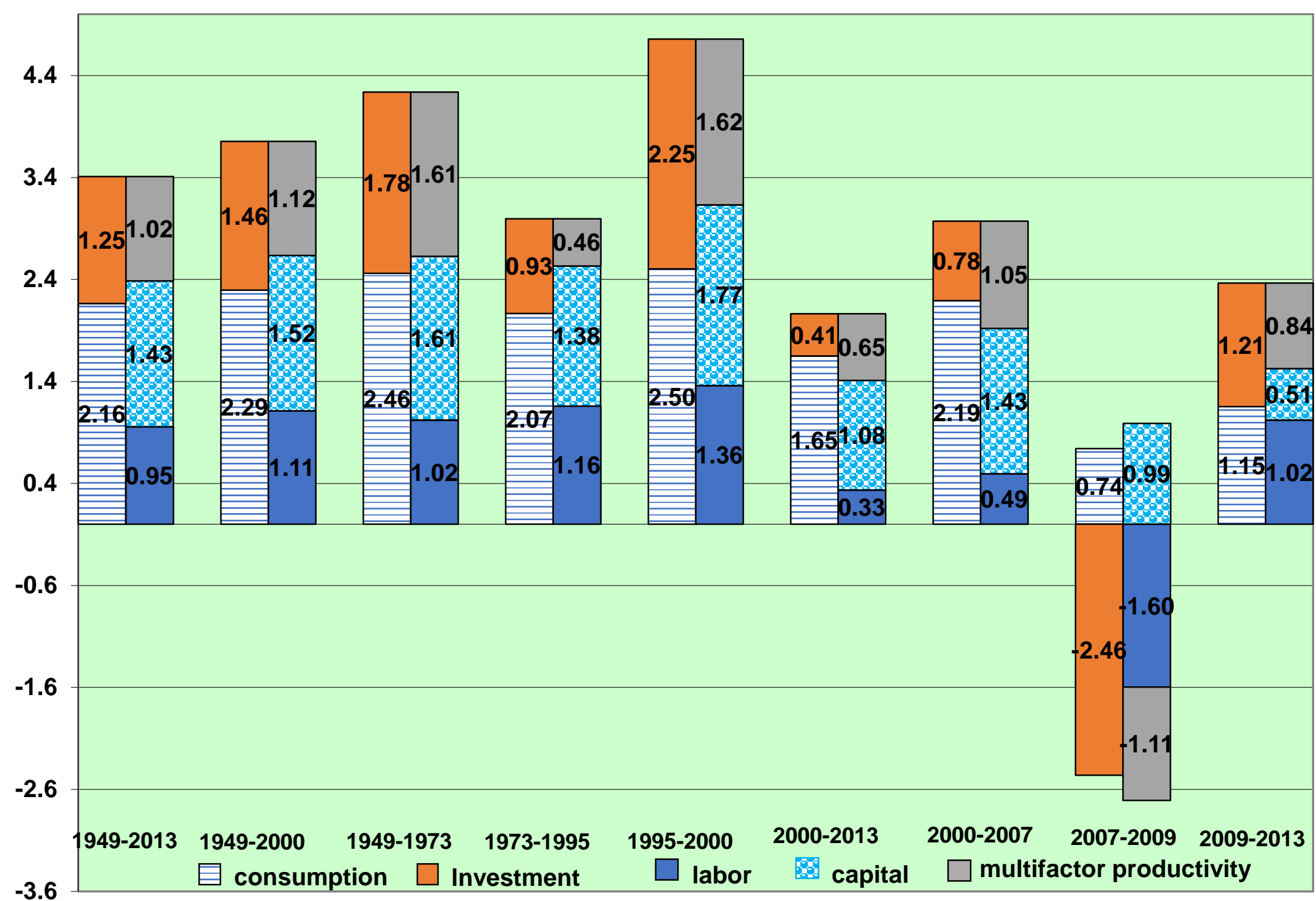


Figure 15 Contributions to expanded gross private domestic product and economic growth with human capital, percentage, 1949-2013

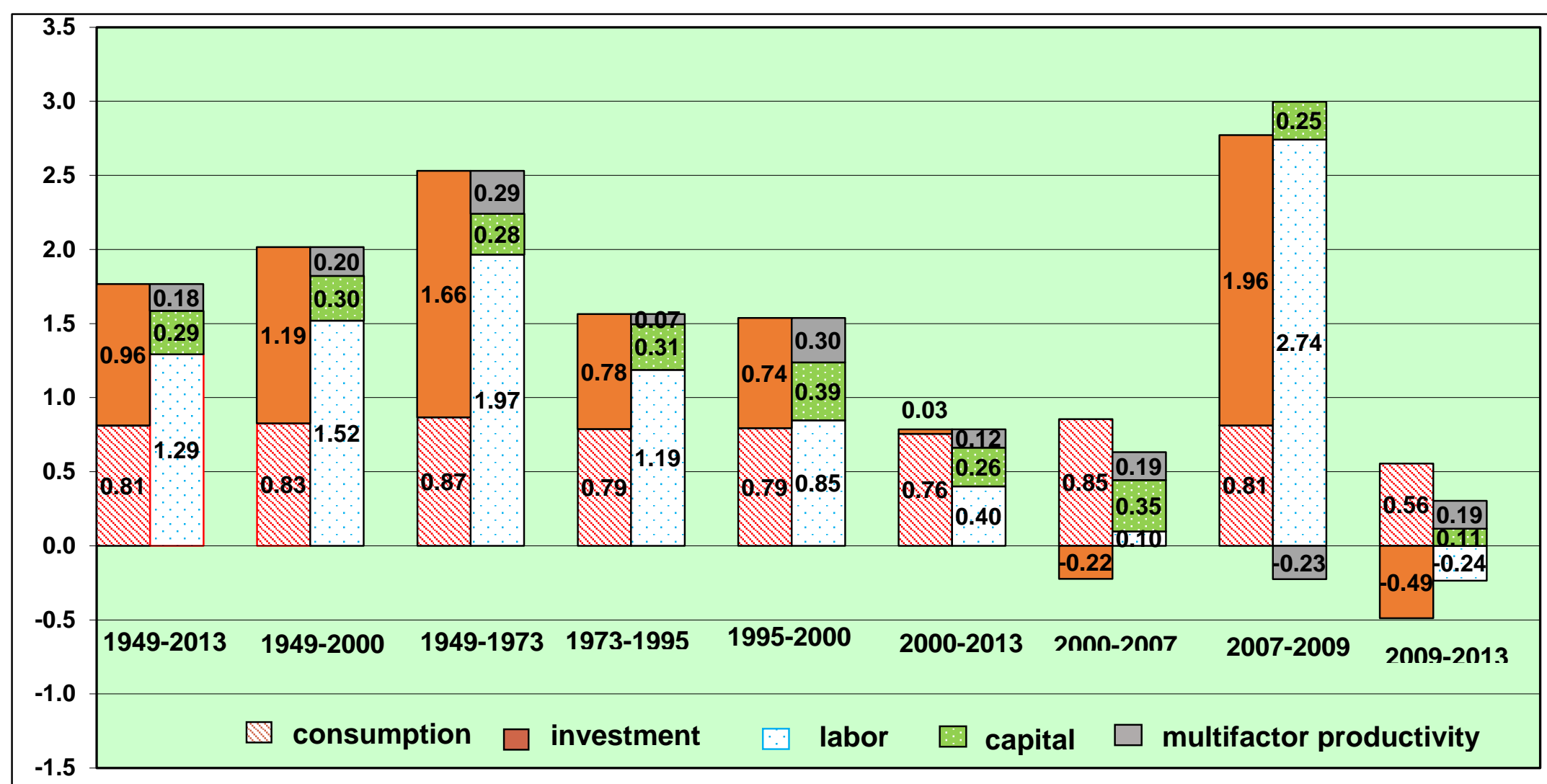


Figure 16 Contributions to expanded Gross Private Domestic Product and economic growth, $1995-2000 \& 2007-9$ subperiods

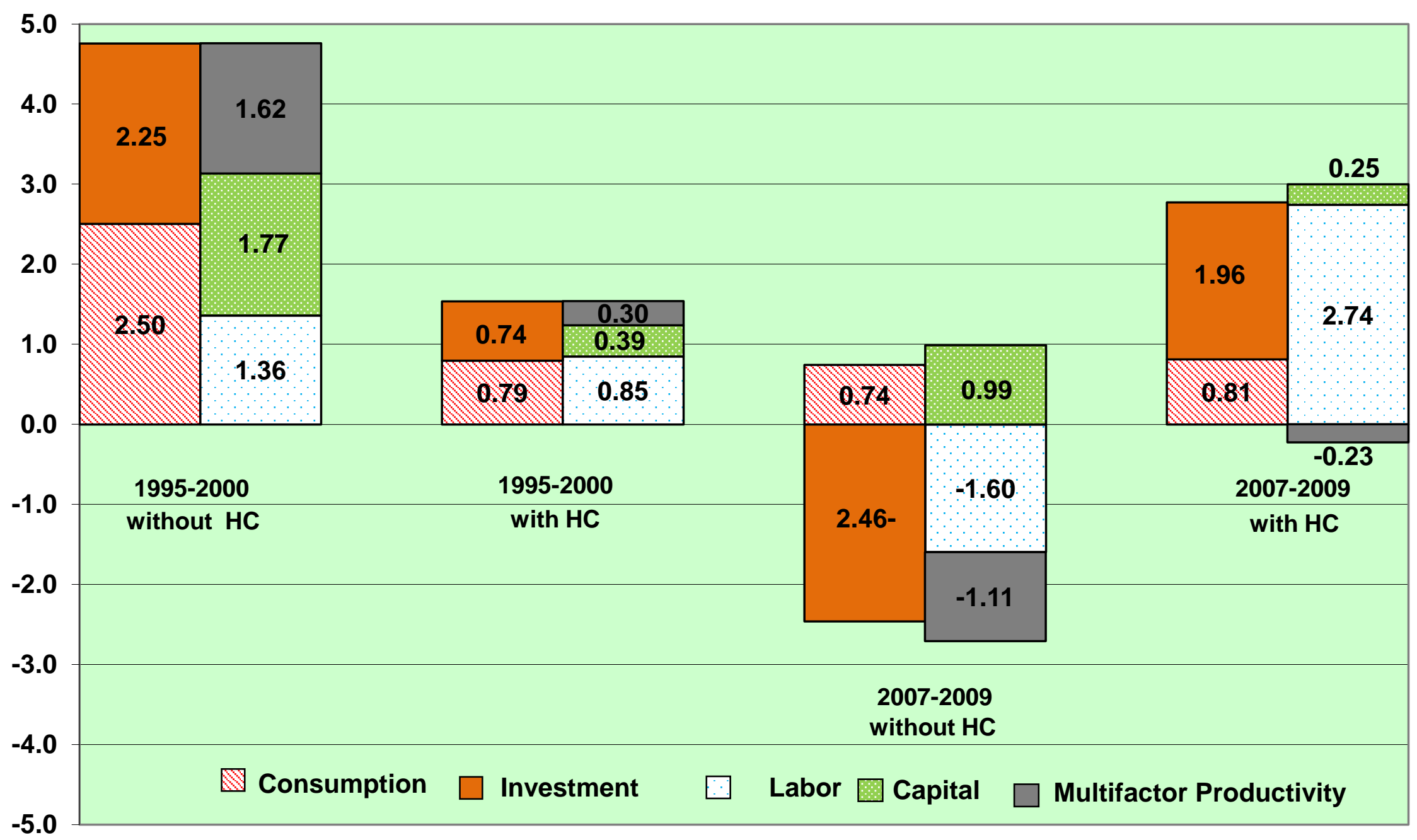


The two most unusual subperiods in this comparison, aside from the differences between the two major subperiods, 1949-2000 and 2000-2013, are the 1995-2000 and 2007-2009 subperiods (see figure 16), and to some extent the recession recovery subperiod 2009-2013. Note that time in household production and leisure is added to expanded consumption, human capital investment is added to expanded investment and both human capital components - time and investment - are added to expanded labor input. Property outlay, labeled capital in the figures, is only a market concept. ${ }^{22}$ The share of expanded investment contribution in total output is always larger in the version with human capital than in the version without human capital in the first major subperiod, 1949-2000. This typical share relationship is due to nominal time in household production and leisure being substantially less than nominal human capital investment. In 19952000 and 2009-2013 in the version without human capital and in 1973-1995 and 1995-2000 in the version with human capital the expanded investment contribution share is 47 to 51 percent, not much different from the expanded consumption contribution share in total output. The share of expanded labor contribution in total input is always larger in the version with human capital than in the version without human capital in the first major subperiod, 1949-2000. This is a result of the size of human capital components. With respect to the shares of expanded output and input, in the other major subperiod, 2000-2013, the relationships are complicated because of a negative contribution in one or the other version. As expected, in both versions, multifactor productivity growth falls beginning in the 1973-1995 subperiod, recovers strongly in 19952000, but falls in 2007-2009 during the Great Recession and recovers in the subperiod 20092013. In all subperiods starting with 1995 or later, there are notable differences in the contributions with and without human capital, as well changes in the relative growth rate of GPDP across subperiods. ${ }^{23}{ }^{24}$ Between 1995 and 2000 and 2000 and 2007, the quantity of human capital investment either rose slightly or fell. By 2000, the difference between the average years of school completed by younger individuals, those 25-34, and older individuals, those aged 5564, narrows considerably (figure 4). In addition, by 1995 tertiary education completion by males aged 25-34 dropped (figure 5). The subperiod 1995-2000 is a remarkable time for the impact of

\footnotetext{
22 Titles in the figures are truncated because of space considerations.

${ }^{23}$ In the "Contributions to expanded Gross Private Domestic Product and economic growth" figures, the following growth rates are included in the calculation of contributions by subperiods.

1949-2013 1949-1950...2012-2013

1949-2000 1949-1950...1999-2000

1949-1973 1949-1950...1972-1973

1973-1995 1973-1974...1994-1995

1995-2000 1995-1996...1999-2000

2000-2013 2000-2001...2012-2013

2000-2007 2000-2001...2006-2007

2007-2009 2007-2008...2008-2009

2009-2013 2009-2010...2012-2013

${ }^{24}$ Contributions are calculated as a weighted rate of growth of quantities in logs, where the weights are the average share of this period's nominal values and last period's nominal values. The multifactor productivity change contribution is the exception as it is the rate of growth of the quantity of output minus the contributions of all inputs.
} 
computers on economic growth, but not for human capital investment. ${ }^{25}$ When human capital is included, the 1973-1995 and 1995-2000 contributions look much more similar.

During the Great Recession years of 2007 through 2009, tertiary education enrollment differs compared to other subperiods, as previously noted, and in time use. Changes in tertiary enrollment percentages and time use shares by either gender are small or nonexistent in the prior period and the later subperiod. From 2006 to 2009, the percentage of individuals aged 18 to 24 enrolled in a post-secondary degree-granting institution increased substantially. From 2006 to 2009, the percent of 18-24 year-old males enrolled in a post-secondary degree-granting institution increased by 4.3 percentage points, from 34.1 to 38.4 percent; for females the comparable figure is 3.6 percentage points, from 40.6 to 44.2 percent. In addition, time use in household production and leisure increased. The share of time devoted to work drops by almost the identical amount that the share of time in household production changes (Fraumeni and Christian, 2019, p. 522). Except for multifactor productivity change, all contributions are positive in 2007-2009 in the version with human capital; in the version without human capital, only two contributions are positive. In 2009-2013, given the trends in human capital investment (years of school and tertiary education completion by males), the economy is weak in the version with human capital.

Appendix table 1 breaks out changes in nominal dollars of major aggregates into quantity and price changes and includes quantity per capita changes, as well as NIPA GDP rates of growth. ${ }^{26}$ ${ }^{27} 28$ Looking at expanded product, the subperiod rates of growth before the 1995-2000 subperiod look different than those after the 1973-1995 subperiod (table 7), except for the 20072009 subperiod. Growth rates for subperiods after the 1973-1995 subperiod almost all drop. Since 1995-2000 is a subperiod of relatively high GDP growth, this may seem surprising. NIPA GDP quantity growth rates are high in the 1949-1973 subperiod, drop in the 1973-1995 subperiod, then return to their previous 1949-1973 level in the 1995-2000 subperiod (see appendix table 1). Similar growth rate trends comparing before the 1995-2000 subperiod and after, except for in the 2007-2009 subperiod, can be seen in the components of output and input

\footnotetext{
${ }^{25}$ Human capital investment in education occurs when individuals are in school.

${ }^{26}$ National population estimates are the basis for per capita figures. See two entries in the bibliography for the Census Bureau, accessed August 23, 2019.

27 The sum of the growth rate of quantity and price always equals the growth rate of nominal dollars, as it must. Growth rates begin in 1949 as quantity figures for 1948 are not always available, as previously noted.

${ }^{28}$ In appendix table 1 and elsewhere, the following growth rates are included in the calculations by subperiods. 1949-2013 1949-1950...2012-2013

1949-2000 1949-1950...1999-2000

1949-1973 1949-1950...1972-1973

1973-1995 1973-1974...1994-1995

1995-2000 1995-1996...1999-2000

2000-2013 2000-2001...2012-2013

2000-2007 2000-2001...2006-2007

2007-2009 2007-2008...2008-2009

2009-2013 2009-2010...2012-2013
} 
appendix tables 1 and 2. The explanation for the differences beginning in the 1995-2000 subperiod, sometimes called the "New Economy" time period, is human capital and multifactor productivity. ${ }^{29}$ Although this chapter breaks out time into two major subperiods, the last beginning in 2000, once human capital is included arguably perhaps the last should begin in 1995.

Table 7 Average rates of growth in expanded production by major subperiods

\begin{tabular}{|r|c|c|}
\hline & \multicolumn{2}{|c|}{ Percentage range of growth rates } \\
\hline Expanded product & $\begin{array}{c}\text { Before 1995-2000 } \\
\text { sub period }\end{array}$ & $\begin{array}{c}\text { After 1973-1995 } \\
\text { sub period, except } \\
\text { for 2007-2009 }\end{array}$ \\
\hline Nominal dollar & 6.1 to 7.4 & 2.0 to 3.7 \\
\hline Quantity & 1.6 to 2.5 & .1 to 1.5 \\
\hline Quantity per capita & .6 to 1.1 & -.7 to .1 \\
\hline Price & 4.3 to 5.8 & 1.9 to 2.6 \\
\hline
\end{tabular}

\section{V.B. Contributions to Expanded Gross Private National Saving and Rates of Growth}

Figure 17 divides gross human and market saving contributions into the contributions of depreciation and net saving. Here, although depreciation reduces net saving, depreciation is shown as an additive component rather than a subtraction from gross saving. For the subperiods 1995-2000, 2000-2007, and 2009-2013, the changes between the previous subperiods 19491973 and 1973-1995 show reductions in expanded components growth similar to those shown in table 7 (appendix table 5). The 2007-2009 subperiod again is an exception. All contributions are positive and higher than in previous subperiods. The contribution of human saving is a result of the impact of school enrollment, as previously noted, and the contribution of depreciation is a result of the aging of the work force, as well as retirements and deaths, and possibly lower earnings per hour as a result of the Great Recession. The negative contribution of human saving in 2009-2013 is a return to pre-2007-2009 trends; the negative contribution of market saving is a

\footnotetext{
${ }^{29}$ Landefeld and Fraumeni (2001).
} 
sign of the weak recovery from the Great Recession. With negative market and human saving contributions, accordingly the contribution of net saving is negative. 
Figure 17 Contributions to expanded gross private national saving

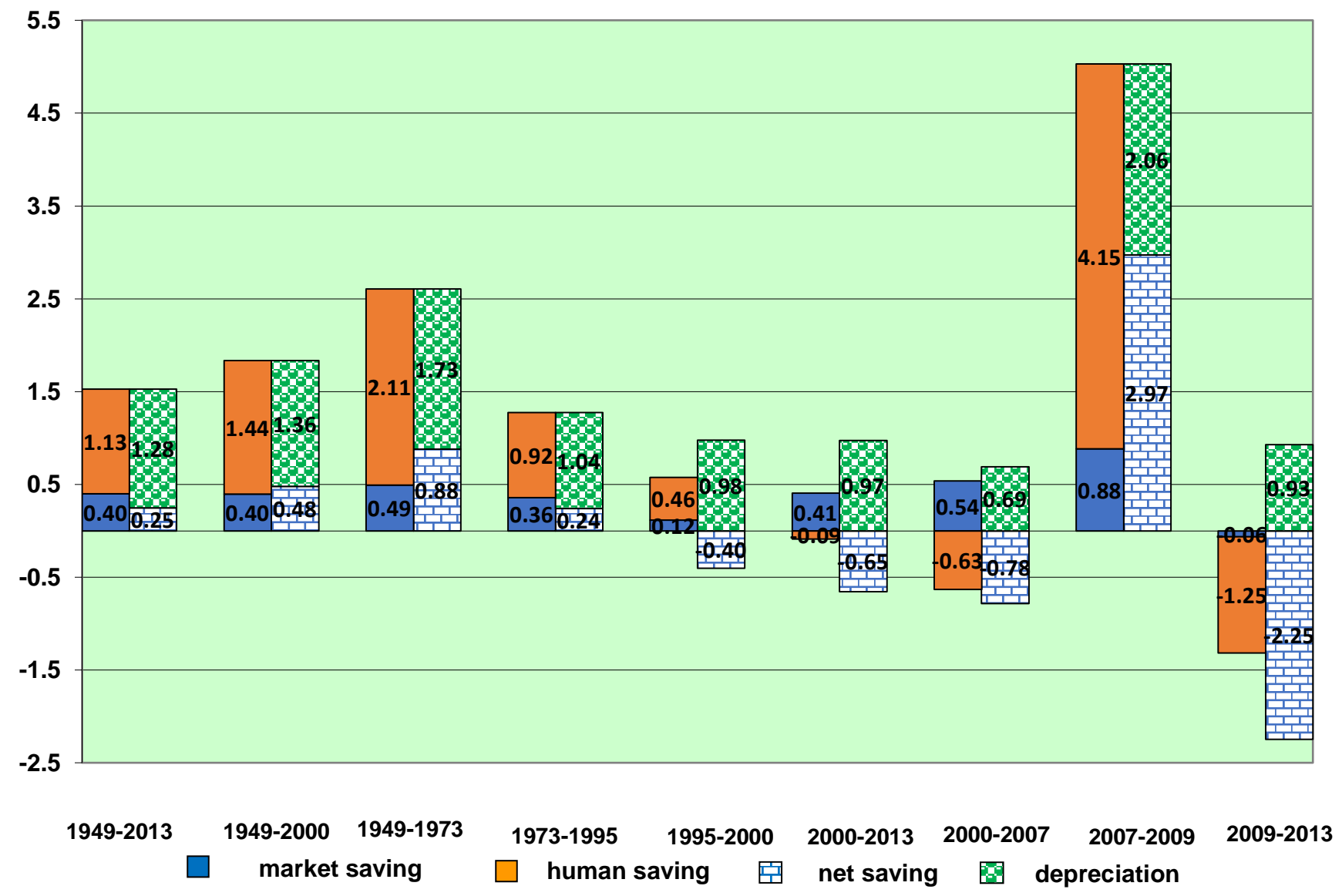




\section{V.C. Contributions to Expanded Private National Expenditure and Income and Rates of Growth}

Most of the major subperiod patterns can be seen in figure 18. The contributions of all the components, except that for property income, decline between 1949-1973 and 1973-1995. In 1995-2000, the contributions of labor income, property income, nonmarket consumption, and net saving are lower than in the previous subperiod. In this figure, the contribution of the level of living is defined as the difference between the contribution of income and expenditures (Samuels, 2018). The contribution of net saving is negative as the contribution of total income is decreasing and the contribution of total consumption is increasing. The contribution of the level of living increases slightly as the negative contribution of net saving offsets to a large extent (and is a result of) the difference between the contribution of total income and the contribution of total consumption. The 2000-2007 subperiod components look somewhat similar to 1995-2000 subperiod components, although the contribution of labor income, market consumption, and net saving fall. Looking at the rates of growth in appendix tables 3 and 4, which underlie contributions, they fall between the periods before 1995-2000 and the 1995-2000 and 20002007 subperiods except for the rates of growth of consumer outlay and property income quantity or quantity per capita. In 2007-2009, primarily because of the impact of investment in education on the contribution of labor income along with the contribution of market consumption being close to zero during the Great Recession, the contribution of net saving becomes a large positive. The probability of 18- to 24-year olds enrolling in post-secondary degree-granting institutions rose significantly as previously described, before declining substantially between 2009 and 2013. ${ }^{30}$ By 2009-2013, the housing crisis had a significant impact on both quantities and prices of residential units, including those that are owner-occupied. ${ }^{31}$ Accordingly, in the 2009-2013 subperiod, the quantity of property income fell and the price of property income rose slightly. In 2009-2013, the contribution of both property income and expanded labor income are negative.

\footnotetext{
${ }^{30}$ Table 302.60, NCES, Digest of Education Statistics 2016. https://nces.ed.gov/programs/digest/d15/tables/dt15_302.60.asp, accessed March 15, 2018.

${ }^{31}$ Property income from owner-occupied housing is imputed.
} 
Figure 18 Contributions to expanded private national expenditure and income, percentage, 1949-2013

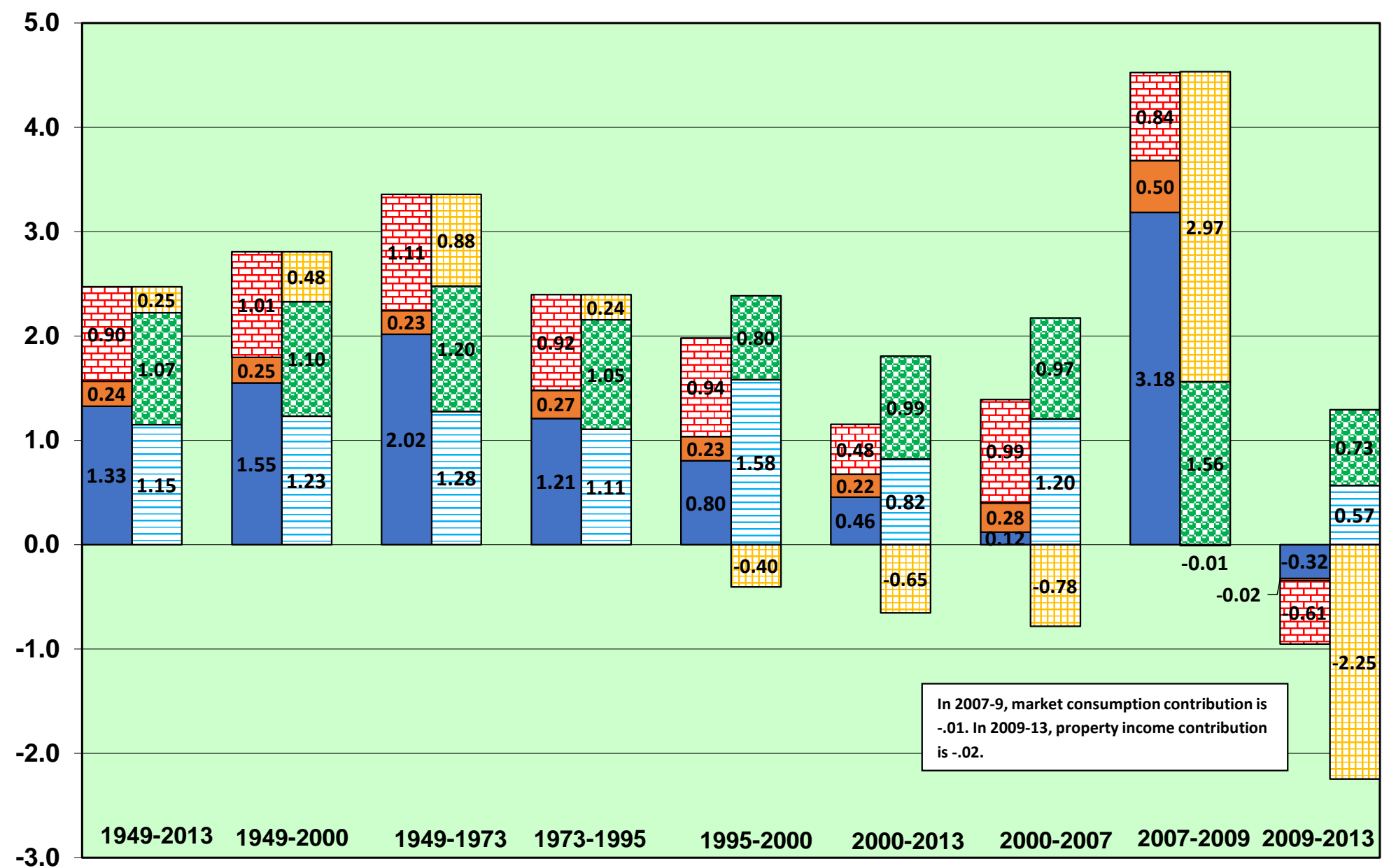

labor income $\square$ property income 圖 level of living $\boxminus$ market consumption 圈 nonmarket consumption $\square$ net saving 


\section{V.D. Contributions to Expanded Private National Wealth and Rates of Growth}

The creation of two major subperiods. 1949-1995 and 1995-2013, is supported by the decrease in rates of growth between the earlier and the later subperiods shown in appendix table 6. Except for all price changes and the quantity of market wealth per capita, the downward trend began as early as the 1973-1995 subperiod. The largest drops are for a wealth subcomponent is for market wealth quantity and quantity per capita between 1995-2000 and 1973-1995. As national population growth slowed in the later subperiods beginning in 2000-2007, it is not surprising that human wealth accretion slows (see appendix table 1 for population rates of growth). The human wealth quantity per capita rate of growth is negative in 1995-2000 and all later subperiods as the rate of national population growth, although low, is higher than the rate of growth of the quantity of human capital.

Beginning in the 1973-1995 subperiod, growth in wealth is less than in 1949-1973 (figure 19). In 1995-2000, this is equally due to a reduction in the contribution of human and market wealth. The contribution of human wealth recovers in 2000-2007 and 2007-2009 and the contribution of market wealth increases between 2000-2007 and 2007-2009. The impact of the Great Recession is finally felt by the 2009-2013 subperiod. As previously noted, increases in enrollments in postsecondary degree institutions by those 18-24 bolstered the 2007-2009 subperiod. The share of human wealth contributions in contributions in total wealth is lower in the second major subperiod, 2000-2013, than in the first major subperiod, 1949-2000, as advancements in the average number of years of school slowed (figure 4). 
Figure 19 Contributions to expanded private national wealth, percentage, 1949-2013

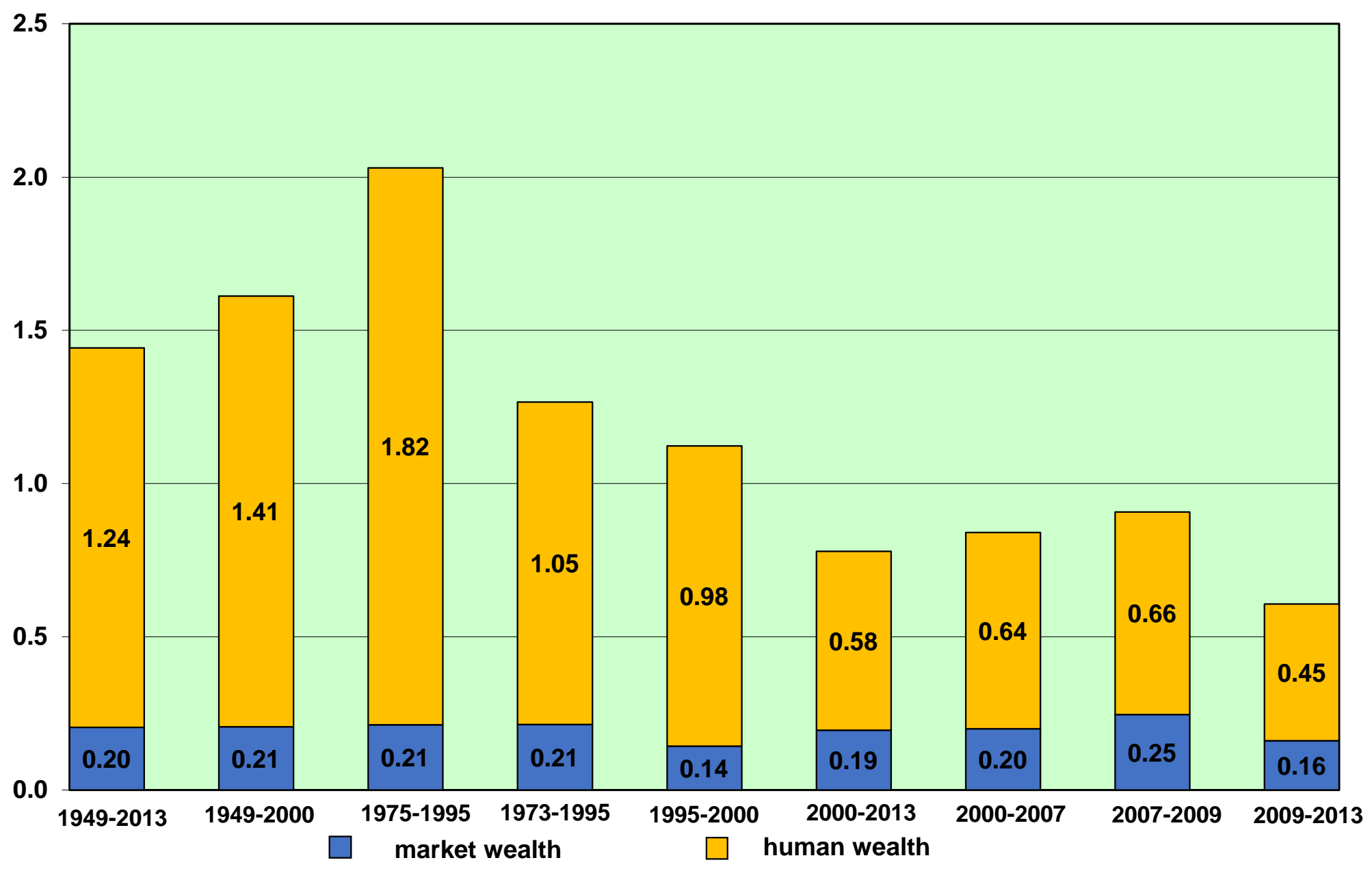




\section{Conclusion}

The accounts that we have presented in this paper demonstrate how to integrate GDP and human capital accounting to assess the sources of economic growth. Including human capital in any analysis of growth is important to understand the drivers of economic growth for any period of time, but particularly so beginning with the 1995-2000 subperiod in the United States. Before 1995-2000, increasing educational attainment is a dependable source of growth, benefitting both the country and individuals. The 1995-2000 "New Economy" subperiod stands out as a subperiod in which market economic growth recovered after the post-1973 slowdown. However, increases in educational attainment noticeably slowed, human capital depreciation from an aging work force became a larger factor, and net saving actually decreased from the previous subperiod. In 2007-2009 total market and human capital growth is less than in 19952000. A bright spot in the 2007-2009 Great Recession subperiod is that human capital investment increased, as the probability that younger individuals would enroll at the postsecondary level went up. This development, which did not continue into the 2009-2013 subperiod, would be missed if human capital was not included in the analysis. In 2009-2013, the contributions of human capital components to economic growth fell. In the future, a positive net contribution of human capital components to economic growth is in doubt given trends with the workforce continuing to age and average educational attainment through higher enrollments no longer surging. Including human capital components in their analysis enables researchers and policy makers to understand the prospects for future growth, as well as how human capital development has interacted with the market sources of growth in the past.

\section{Bibliography}

Barro, R., Lee, J. 2013a. A new data set of educational attainment in the world, 19502010. Journal of Development Economics. 104(C). p. 184-198.

Barro, R., Lee, J. 2013b. Barro-Lee educational attainment data set. Last updated April 9, 2013. http://www.barrolee.com/, accessed October 2013.

Bernanke, B. 2004. The great moderation. February 20. Remarks by Governor Ben S. Bernanke, at the meetings of the Eastern Economic Association, Washington, DC, February 20. https://www.federalreserve.gov/boarddocs/speeches/2004/20040220/default.htm, accessed November 17, 2019.

Boskin, M. J. 2000. Getting the 21st-century GDP right, economic measurement: Progress and challenges. American Economic Review, Papers and Proceedings 90 (2) May, 247-252.

Bureau of Economic Analysis, U.S. Department of Commerce. 2013. Preview of the 2013 comprehensive revision of the National Income and Product Accounts, changes in definitions and presentations. Survey of Current Business. U.S. Government Printing Office, Washington, D.C., March, 13-39. 
Bureau of Economic Analysis, U.S. Department of Commerce. Various years. Survey of Current Business. U.S Government Printing Office, Washington, DC.

Bureau of Economic Analysis, U.S. Department of Commerce. 2017. National Income and Product Accounts. July 28.

Census Bureau, U.S. Department of Commerce. Historical Income Tables: People. https://www.census.gov/data/tables/time-series/demo/income-poverty/historical-incomepeople.html, accessed July 29, 2019.

Census Bureau, U.S. Department of Commerce. American FactFinder. https://factfinder.census.gov/faces/tableservices/jsf/pages/productview.xhtml?pid=PEP_2018_PE PANNRES\&prodType=table, accessed August 23, 2019.

Census Bureau, U.S. Department of Commerce. 1975. Bicentennial Edition: Historical Statistics of the United States, Colonial Times to the Present. U.S Government Printing Office, Washington, DC.

Census Bureau, U.S. Department of Commerce. 2015. Current Population Survey, Annual Social and Economic Supplements. U.S Government Printing Office, Washington, DC.

Census Bureau, U.S. Department of Commerce. Population Estimates Program, Population Division. Internet release Date: April 11, 2000, Revised date: June 28, 2000, https://www.census.gov/population/estimates/nation/popclockest.txt, accessed August 23, 2019. 2000.

Census Bureau, U.S. Department of Commerce. Table P-40 Women's Earnings as a Percentage of Men's Earnings by Race and Hispanic Origin: 1960 to 2018, https://www.census.gov/data/tables/time-series/demo/income-poverty/historical-incomepeople.html, accessed November 19, 2019.

Census Bureau, U.S. Department of Commerce. Table P-42 Work experience--All workers by mean earnings and sex: 1967 to 2018, https://www.census.gov/data/tables/timeseries/demo/income-poverty/historical-income-people.html, accessed November 15, 2019.

Centers for Disease Control and Prevention, National Center for Health Statistics. Life tables. https://www.cdc.gov/nchs/products/life_tables.htm.

Christian M. S. 2017. Net investment and stocks of human capital in the United States, 19752013, International Productivity Monitor 33 Fall, 128-149.

Fraumeni, B.M., Christian, M.S. 2019. Accumulation of human and market capital in the United States, 1975-2012: An analysis by gender. In Fraumeni, B. M. (Ed.), Measuring Economic Growth and Productivity, Foundations, KLEM Production Models, and Extensions. Academic Press, Cambridge, MA, 509-529.

Fraumeni, B.M., Christian, M.S., Samuels, J.D. 2017. The accumulation of human and nonhuman capital, revisited. Review of Income and Wealth 63 (supplement 2) pp. S381-S410. 
Gollop, F.M., Jorgenson, D.W. 1980. U.S. productivity growth by industry, 1947-73. In Kendrick, J.W. and Vaccara, B.N. (Eds.), New Developments in Productivity Measurement and Analysis. University of Chicago Press, NBER, Chicago, 17-136.

Gollop, F.M., Jorgenson, D.W. 1983. Sectoral measures of labor cost of the United States, 19481979. In Triplett, J.E. (Ed.), The Measurement of Labor Cost, University of Chicago Press, NBER, Chicago, 185-235.

Jaszi, G., Kendrick, J.W., 1951. Estimate of Gross National Product in constant dollars, 1929-49. Survey of Current Business. Office of Business Economics, Bureau of Domestic and Foreign Commerce, U.S Department of Commerce, U.S Government Printing Office, Washington, D.C., 6-11.

Jorgenson, Dale W. 2010. Designing a new architecture for the U.S. national accounts. The Annals of the American Academy of Political and Social Science, 631, no. 1, 63-74.

Jorgenson, D.W., Fraumeni, B.M., 1992a. Investment in education and U.S. economic growth. Scandinavian Journal of Economics, 94 (supplement), S51-70.

Jorgenson, D.W., Fraumeni, B.M., 1989. The accumulation of human and nonhuman capital, 1948-1984. In Lipsey, R. and Tice, H. (Eds.) The Measurement of Saving, Investment and Wealth. University of Chicago Press, NBER, Chicago, 227-282.

Jorgenson, D.W., Fraumeni, B.M., 1992b. The output of the education sector. In Griliches, Z., Breshnahan, T., Manser, M. and Berndt, E. (Eds.), The Output of the Service Sector. University of Chicago Press, NBER, Chicago, 303-341.

Landefeld, J. S., Fraumeni, B.M., 2001. Measuring the New Economy. Survey of Current Business. March, 23-40.

Jorgenson, D. W. Landefeld, J.S., 2006. Blueprint for expanded and integrated U.S. accounts: review, assessment, and next steps. In D. W. Jorgenson, D.W., Landefeld, J.S., Nordhaus, W.D. (Eds.), A New Architecture for the U.S. National Accounts. University of Chicago Press, NBER, Chicago, 13-112, 2006.

Jorgenson, D.W., Landefeld, J.S. 2009. Implementation of a new architecture for the U.S. national accounts. American Economic Review, Papers and Proceedings, volume 99, number 2, May, 64-68.

National Bureau of Economic Research. 2019. US business cycle expansions and contractions. http://wwwdev.nber.org/cycles/cyclesmain.html, accessed July 23, 2019.

National Center for Education Statistics. 2018. Digest of Education Statistics: 2016. http://nces.ed.gov/programs/digest/d15/tables/dt15_302.60.asp_accessed March 15, 2018.

Samuels J. D. 2018. Aggregate productivity and the level of living, and estimates for 1948-2016, unpublished manuscript, presented at the International Association for Research in Income and 
Wealth conference, Copenhagen, Denmark, http://www.iariw.org/c2018copenhagen.php, August 20.

Toosi, M. 2002. A century of change: the U.S. labor force, 1950-2050: With slower growth, aging, and increasing diversity, the profile of the U.S. labor force is undergoing a gradual, but significant, change. Monthly Labor Review. Bureau of Labor Statistics, U.S. Department of Labor, Washington, DC. May, 15-28.

Toosi, M. 2012. Labor force projections to 2020: A more slowly growing workforce. Monthly Labor Review. Bureau of Labor Statistics, U.S. Department of Labor, Washington, DC. January, 43-64. 
Appendix table 1 NIPA Gross Domestic Product and expanded Gross Private Domestic Product, rates of growth, 1949-2013

\begin{tabular}{|c|c|c|c|c|c|c|c|c|c|}
\hline & $\begin{array}{l}1949- \\
2013 \\
\end{array}$ & $\begin{array}{l}1949- \\
2000\end{array}$ & $\begin{array}{l}1949- \\
1973 \\
\end{array}$ & $\begin{array}{c}1973- \\
1995 \\
\end{array}$ & $\begin{array}{l}1995 \\
2000\end{array}$ & $\begin{array}{c}2000- \\
2013 \\
\end{array}$ & $\begin{array}{l}2000- \\
2007\end{array}$ & $\begin{array}{l}2007- \\
2009 \\
\end{array}$ & $\begin{array}{c}2009- \\
2013\end{array}$ \\
\hline National population & 0.0117 & 0.0125 & 0.0146 & 0.0098 & 0.0142 & 0.0087 & 0.0093 & 0.0091 & 0.0075 \\
\hline NIPA GDP quantity & 0.0320 & 0.0359 & 0.0414 & 0.0286 & 0.0421 & 0.0167 & 0.0242 & -0.0155 & 0.0199 \\
\hline \multicolumn{10}{|l|}{ Expanded product: } \\
\hline Nominal dollar & 0.0607 & 0.0682 & 0.0696 & 0.0737 & 0.0371 & 0.0316 & 0.0324 & 0.0521 & 0.0199 \\
\hline Quantity & 0.0177 & 0.0202 & 0.0253 & 0.0156 & 0.0154 & 0.0079 & 0.0063 & 0.0277 & 0.0007 \\
\hline Quantity per capita & 0.0059 & 0.0077 & 0.0107 & 0.0059 & 0.0012 & -0.0009 & -0.0030 & 0.0186 & -0.0068 \\
\hline Price & 0.0431 & 0.0480 & 0.0443 & 0.0580 & 0.0217 & 0.0237 & 0.0261 & 0.0243 & 0.0192 \\
\hline \multicolumn{10}{|l|}{ Expanded investment: } \\
\hline Nominal dollar & 0.0603 & 0.0693 & 0.0722 & 0.0749 & 0.0308 & 0.0252 & 0.0210 & 0.0532 & 0.0187 \\
\hline Quantity & 0.0149 & 0.0185 & 0.0259 & 0.0121 & 0.0115 & 0.0006 & -0.0035 & 0.0329 & -0.0083 \\
\hline Quantity per capita & 0.0032 & 0.0060 & 0.0113 & 0.0023 & -0.0027 & -0.0081 & -0.0129 & 0.0238 & -0.0158 \\
\hline Price & 0.0455 & 0.0508 & 0.0463 & 0.0628 & 0.0193 & 0.0246 & 0.0245 & 0.0203 & 0.0270 \\
\hline \multicolumn{10}{|c|}{ Expanded consumption: } \\
\hline Nominal dollar & 0.0613 & 0.0663 & 0.0652 & 0.0714 & 0.0490 & 0.0418 & 0.0509 & 0.0504 & 0.0216 \\
\hline Quantity & 0.0223 & 0.0231 & 0.0245 & 0.0217 & 0.0225 & 0.0192 & 0.0222 & 0.0201 & 0.0135 \\
\hline Quantity per capita & 0.0106 & 0.0106 & 0.0099 & 0.0119 & 0.0083 & 0.0105 & 0.0128 & 0.0110 & 0.0061 \\
\hline Price & 0.0390 & 0.0432 & 0.0407 & 0.0498 & 0.0265 & 0.0226 & 0.0287 & 0.0303 & 0.0081 \\
\hline
\end{tabular}

Sources: NIPA GDP rates of growth are computed from NIPA table 1.1.1, which lists data published July 28, 2017.

Other rates of growth are from the authors' estimates. 
Appendix table 2 Expanded gross private domestic factor outlay, rates of growth, 1949-2013

\begin{tabular}{|c|c|c|c|c|c|c|c|c|c|}
\hline & $\begin{array}{l}1949- \\
2013\end{array}$ & $\begin{array}{l}1949- \\
2000\end{array}$ & $\begin{array}{c}1949- \\
1973\end{array}$ & $\begin{array}{c}1973- \\
1995\end{array}$ & $\begin{array}{l}1995 \\
2000\end{array}$ & $\begin{array}{l}2000- \\
2013\end{array}$ & $\begin{array}{l}2000- \\
2007\end{array}$ & $\begin{array}{l}2007- \\
2009\end{array}$ & $\begin{array}{l}2009- \\
2013\end{array}$ \\
\hline \multicolumn{10}{|c|}{ Expanded factor outlay: } \\
\hline Nominal dollar & 0.0607 & 0.0682 & 0.0696 & 0.0737 & 0.0371 & 0.0316 & 0.0324 & 0.0521 & 0.0199 \\
\hline Quantity & 0.0158 & 0.0181 & 0.0225 & 0.0147 & 0.0121 & 0.0065 & 0.0041 & 0.0302 & -0.0012 \\
\hline Quantity per capita & 0.0040 & 0.0056 & 0.0078 & 0.0050 & -0.0021 & -0.0022 & -0.0053 & 0.0211 & -0.0086 \\
\hline Price & 0.0450 & 0.0501 & 0.0471 & 0.0589 & 0.0250 & 0.0251 & 0.0284 & 0.0219 & 0.0211 \\
\hline \multicolumn{10}{|l|}{ Expanded labor outlay: } \\
\hline Nominal dollar & 0.0603 & 0.0679 & 0.0697 & 0.0732 & 0.0362 & 0.0305 & 0.0299 & 0.0530 & 0.0205 \\
\hline Quantity & 0.0141 & 0.0165 & 0.0212 & 0.0132 & 0.0094 & 0.0046 & 0.0011 & 0.0310 & -0.0025 \\
\hline Quantity per capita & 0.0024 & 0.0041 & 0.0065 & 0.0034 & -0.0049 & -0.0041 & -0.0082 & 0.0219 & -0.0100 \\
\hline Price & 0.0462 & 0.0514 & 0.0486 & 0.0600 & 0.0268 & 0.0259 & 0.0287 & 0.0220 & 0.0230 \\
\hline \multicolumn{10}{|l|}{ Property outlay: } \\
\hline Nominal dollar & 0.0651 & 0.0709 & 0.0676 & 0.0799 & 0.0474 & 0.0423 & 0.0576 & 0.0436 & 0.0149 \\
\hline Quantity & 0.0339 & 0.0361 & 0.0387 & 0.0322 & 0.0411 & 0.0251 & 0.0338 & 0.0226 & 0.0112 \\
\hline Quantity per capita & 0.0222 & 0.0236 & 0.0241 & 0.0224 & 0.0269 & 0.0164 & 0.0244 & 0.0135 & 0.0038 \\
\hline Price & 0.0312 & 0.0348 & 0.0289 & 0.0477 & 0.0063 & 0.0172 & 0.0238 & 0.0210 & 0.0037 \\
\hline
\end{tabular}


Appendix table 3 Expanded private national income, rates of growth, 1949-2013

\begin{tabular}{|c|c|c|c|c|c|c|c|c|c|}
\hline & $\begin{array}{l}1949- \\
2013\end{array}$ & $\begin{array}{l}1949- \\
2000\end{array}$ & $\begin{array}{c}1949- \\
1973\end{array}$ & $\begin{array}{c}1973- \\
1995\end{array}$ & $\begin{array}{l}1995 \\
2000\end{array}$ & $\begin{array}{l}2000- \\
2013\end{array}$ & $\begin{array}{l}2000- \\
2007\end{array}$ & $\begin{array}{l}2007- \\
2009\end{array}$ & $\begin{array}{l}2009- \\
2013\end{array}$ \\
\hline \multicolumn{10}{|c|}{ Expanded national income: } \\
\hline Nominal dollar & 0.0607 & 0.0680 & 0.0697 & 0.0737 & 0.0352 & 0.0320 & 0.0329 & 0.0580 & 0.0174 \\
\hline Quantity & 0.0159 & 0.0182 & 0.0227 & 0.0149 & 0.0106 & 0.0069 & 0.0040 & 0.0369 & -0.0033 \\
\hline Quantity per capita & 0.0041 & 0.0057 & 0.0081 & 0.0051 & -0.0036 & -0.0019 & -0.0053 & 0.0278 & -0.0107 \\
\hline Price index & 0.0449 & 0.0499 & 0.0469 & 0.0588 & 0.0246 & 0.0252 & 0.0289 & 0.0211 & 0.0207 \\
\hline \multicolumn{10}{|c|}{ Expanded labor income: } \\
\hline Nominal dollar & 0.0603 & 0.0678 & 0.0698 & 0.0730 & 0.0351 & 0.0309 & 0.0306 & 0.0560 & 0.0189 \\
\hline Quantity & 0.0142 & 0.0166 & 0.0214 & 0.0131 & 0.0087 & 0.0050 & 0.0013 & 0.0349 & -0.0036 \\
\hline Quantity per capita & 0.0025 & 0.0041 & 0.0068 & 0.0033 & -0.0055 & -0.0037 & -0.0080 & 0.0258 & -0.0110 \\
\hline Price index & 0.0461 & 0.0512 & 0.0484 & 0.0599 & 0.0264 & 0.0259 & 0.0293 & 0.0211 & 0.0225 \\
\hline \multicolumn{10}{|l|}{ Property income: } \\
\hline Nominal dollar & 0.0660 & 0.0715 & 0.0671 & 0.0842 & 0.0364 & 0.0444 & 0.0588 & 0.0779 & 0.0024 \\
\hline Quantity & 0.0347 & 0.0367 & 0.0382 & 0.0365 & 0.0300 & 0.0268 & 0.0349 & 0.0567 & -0.0025 \\
\hline Quantity per capita & 0.0229 & 0.0242 & 0.0235 & 0.0268 & 0.0157 & 0.0180 & 0.0256 & 0.0476 & -0.0099 \\
\hline Price & 0.0313 & 0.0348 & 0.0290 & 0.0477 & 0.0064 & 0.0176 & 0.0239 & 0.0212 & 0.0049 \\
\hline
\end{tabular}


Appendix table 4 Expanded private national expenditures, rates of growth, 1949-2013

\begin{tabular}{llllllllrr}
\hline & $1949-$ & $1949-$ & $1949-$ & $1973-$ & 1995 & $2000-$ & $2000-$ & $2007-$ & $2009-$ \\
& 2013 & 2000 & 1973 & 1995 & 2000 & 2013 & 2007 & 2009 & 2013 \\
\hline Expanded expenditures: & & & & & & & & & \\
$\quad$ Nominal dollar & 0.0609 & 0.0681 & 0.0697 & 0.0739 & 0.0353 & 0.0324 & 0.0334 & 0.0595 & 0.0172 \\
Quantity & 0.0179 & 0.0201 & 0.0255 & 0.0161 & 0.0122 & 0.0091 & 0.0079 & 0.0362 & -0.0025 \\
Quantity per capita & 0.0062 & 0.0076 & 0.0109 & 0.0063 & -0.0020 & 0.0003 & -0.0014 & 0.0271 & -0.0099 \\
Price index & 0.0430 & 0.0480 & 0.0442 & 0.0578 & 0.0231 & 0.0233 & 0.0255 & 0.0233 & 0.0197 \\
Expanded consumer outlays: & & & & & & & & \\
$\quad$ Nominal dollar & 0.0615 & 0.0666 & 0.0653 & 0.0717 & 0.0505 & 0.0413 & 0.0511 & 0.0458 & 0.0219 \\
Quantity & 0.0222 & 0.0233 & 0.0248 & 0.0216 & 0.0238 & 0.0181 & 0.0217 & 0.0155 & 0.0129 \\
Quantity per capita & 0.0105 & 0.0108 & 0.0101 & 0.0118 & 0.0096 & 0.0093 & 0.0124 & 0.0064 & 0.0055 \\
Price index & 0.0392 & 0.0433 & 0.0406 & 0.0501 & 0.0266 & 0.0232 & 0.0293 & 0.0303 & 0.0090 \\
Expanded gross saving: & & & & & & & & \\
$\quad$ Nominal dollar & 0.0605 & 0.0690 & 0.0723 & 0.0750 & 0.0270 & 0.0268 & 0.0220 & 0.0690 & 0.0140 \\
Quantity & 0.0153 & 0.0183 & 0.0261 & 0.0128 & 0.0058 & 0.0032 & -0.0009 & 0.0503 & -0.0132 \\
Quantity per capita & 0.0035 & 0.0058 & 0.0115 & 0.0030 & -0.0085 & -0.0055 & -0.0103 & 0.0412 & -0.0206 \\
Price & 0.0452 & 0.0507 & 0.0462 & 0.0623 & 0.0213 & 0.0236 & 0.0229 & 0.0187 & 0.0271 \\
\hline
\end{tabular}


Appendix Table 5 Expanded Gross Private National Saving, rates of growth, 1949-2013

\begin{tabular}{|c|c|c|c|c|c|c|c|c|c|}
\hline & $\begin{array}{l}1949- \\
2013\end{array}$ & $\begin{array}{l}1949- \\
2000\end{array}$ & $\begin{array}{c}1949- \\
1973\end{array}$ & $\begin{array}{c}1973- \\
1995\end{array}$ & $\begin{array}{l}1995 \\
2000\end{array}$ & $\begin{array}{l}2000- \\
2013\end{array}$ & $\begin{array}{l}2000- \\
2007\end{array}$ & $\begin{array}{l}2007- \\
2009\end{array}$ & $\begin{array}{l}2009- \\
2013\end{array}$ \\
\hline \multicolumn{10}{|l|}{ Expanded gross saving: } \\
\hline Nominal dollar & 0.0605 & 0.0690 & 0.0723 & 0.0750 & 0.0270 & 0.0268 & 0.0220 & 0.0690 & 0.0140 \\
\hline Quantity & 0.0153 & 0.0183 & 0.0261 & 0.0128 & 0.0058 & 0.0032 & -0.0009 & 0.0503 & -0.0132 \\
\hline Quantity per capita & 0.0035 & 0.0058 & 0.0115 & 0.0030 & -0.0085 & -0.0055 & -0.0103 & 0.0412 & -0.0206 \\
\hline Price index & 0.0452 & 0.0507 & 0.0462 & 0.0623 & 0.0213 & 0.0236 & 0.0229 & 0.0187 & 0.0271 \\
\hline \multicolumn{10}{|l|}{ Expanded depreciation: } \\
\hline Nominal dollar & 0.0628 & 0.0695 & 0.0710 & 0.0764 & 0.0315 & 0.0368 & 0.0338 & 0.0308 & 0.0450 \\
\hline Quantity & 0.0172 & 0.0187 & 0.0246 & 0.0136 & 0.0126 & 0.0116 & 0.0084 & 0.0243 & 0.0109 \\
\hline Quantity per capita & 0.0055 & 0.0062 & 0.0099 & 0.0039 & -0.0016 & 0.0029 & -0.0009 & 0.0152 & 0.0034 \\
\hline Price index & 0.0456 & 0.0508 & 0.0464 & 0.0628 & 0.0189 & 0.0252 & 0.0254 & 0.0064 & 0.0341 \\
\hline \multicolumn{10}{|l|}{ Expanded net saving: } \\
\hline Nominal dollar & 0.0486 & 0.0676 & 0.0762 & 0.0709 & 0.0117 & -0.0260 & -0.0304 & 0.2412 & -0.1519 \\
\hline Quantity & 0.0060 & 0.0177 & 0.0318 & 0.0101 & -0.0162 & -0.0396 & -0.0419 & 0.1615 & -0.1363 \\
\hline Quantity per capita & -0.0057 & 0.0052 & 0.0171 & 0.0003 & -0.0304 & -0.0484 & -0.0513 & 0.1524 & -0.1437 \\
\hline Price & 0.0425 & 0.0499 & 0.0445 & 0.0608 & 0.0280 & 0.0136 & 0.0115 & 0.0797 & -0.0156 \\
\hline
\end{tabular}


Appendix Table 6 Expanded Private National Wealth, rates of growth, 1949-2013

\begin{tabular}{|c|c|c|c|c|c|c|c|c|c|}
\hline & $\begin{array}{l}1949- \\
2013\end{array}$ & $\begin{array}{l}1949- \\
2000\end{array}$ & $\begin{array}{c}1949- \\
1973\end{array}$ & $\begin{array}{l}1973- \\
1995\end{array}$ & $\begin{array}{l}1995 \\
2000\end{array}$ & $\begin{array}{l}2000- \\
2013\end{array}$ & $\begin{array}{l}2000- \\
2007\end{array}$ & $\begin{array}{l}2007- \\
2009\end{array}$ & $\begin{array}{l}2009- \\
2013\end{array}$ \\
\hline \multicolumn{10}{|l|}{ Expanded wealth: } \\
\hline Nominal dollar & 0.0593 & 0.0654 & 0.0685 & 0.0658 & 0.0486 & 0.0355 & 0.0482 & 0.0270 & 0.0176 \\
\hline Quantity per capita & 0.0027 & 0.0036 & 0.0057 & 0.0029 & -0.0030 & -0.0009 & -0.0009 & 0.0000 & -0.0014 \\
\hline Price index & 0.0449 & 0.0493 & 0.0482 & 0.0532 & 0.0373 & 0.0277 & 0.0398 & 0.0179 & 0.0115 \\
\hline \multicolumn{10}{|l|}{ Human wealth: } \\
\hline Quantity & 0.0133 & 0.0150 & 0.0193 & 0.0113 & 0.0106 & 0.0064 & 0.0071 & 0.0072 & 0.0049 \\
\hline Quantity per capita & 0.0015 & 0.0025 & 0.0047 & 0.0015 & -0.0036 & -0.0023 & -0.0023 & -0.0019 & -0.0026 \\
\hline Price index & 0.0455 & 0.0499 & 0.0493 & 0.0535 & 0.0369 & 0.0284 & 0.0387 & 0.0292 & 0.0100 \\
\hline \multicolumn{10}{|l|}{ Market wealth: } \\
\hline Nominal dollar & 0.0658 & 0.0717 & 0.0657 & 0.0805 & 0.0610 & 0.0428 & 0.0728 & -0.0697 & 0.0465 \\
\hline Quantity & 0.0296 & 0.0316 & 0.0359 & 0.0300 & 0.0184 & 0.0219 & 0.0219 & 0.0277 & 0.0190 \\
\hline
\end{tabular}

